The

University

of Chicago

Law Review

- 1981 by The University of Chicago

\title{
State "Citizenship" and Interstate Equality
}

\author{
Jonathan D. Varat $\dagger$
}

From the nation's inception, explicit constitutional provisions have limited state power to discriminate against the inhabitants of other states." In order "to secure and perpetuate mutual friendship and intercourse among the people of the different states in this union," the Articles of Confederation declared the principle that each state generally must treat the residents of sister states as it would treat its own. ${ }^{2}$ When the Constitution was first adopted, it

$\dagger$ Acting Professor of Law, University of California (Los Angeles). I am grateful to my colleagues Theodore Eisenberg, Kenneth L. Karst, William A. Klein, Gerald P. Lopez, Daniel H. Lowenstein, Gary T. Schwartz, Murray L. Schwartz, and Steven Shiffrin for generous readings and constructive criticisms of prior versions of this article.

${ }^{1}$ In 1776, even before the American colonies became states, a committee of the Continental Congress, appointed to propose articles of confederation, drafted two articles protecting the inhabitants of one colony from discrimination by another. See Antieau, Paul's Perverted Privileges or the True Meaning of the Privileges and Immunities Clause of Article Four, 9 WM. \& MARY L. REv. 1, 2-5 (1967). English law protective of "alien friends" is traced to the Magna Carta in R. Howell, The Privirgars and Immunities of State CitTZENSHIP 9-13 (1918). Howell further claimed that, by the time of the Articles of Confederation, "independently of any constitutional provision, the citizens of the thirteen original states were entitled to the enjoyment of a considerable class of privileges upon removal from their own to another State." Id. at 13. In his view, the constitutional provisions were drafted to extend the scope of these protections and render them more secure. Id.

a Article IV of the Articles of Confederation provided:

The better to secure and perpetuate mutual friendship and intercourse among the people of the different states in this union, the free inhabitants of each of these states, paupers, vagabonds and fugitives from justice excepted, shall be entitled to all privileges and immunities of free citizens in the several states; and the people of each state 
embodied this principle in two separate provisions. The article I grant to Congress of the power to regulate interstate commerce ${ }^{3}$ implicitly curtailed state power to affect that commerce; ${ }^{4}$ one of the core limits imposed was a ban on state discrimination against commercial relationships between one state's residents and another's. ${ }^{5}$ Article IV, the states' relations article, spoke more di-

shall have free ingress and regress to and from any other state, and shall enjoy therein all the privileges of trade and commerce, subject to the same duties, impositions and restrictions as the inhabitants thereof respectively, provided that such restriction shall not extend so far as to prevent the removal of property imported into any state, to any other state, of which the Owner is an inhabitant; provided also that no imposition, duties, or restriction shall be laid by any state, on the property of the united states, or either of them.

19 Journals of the Continental Congress 214-15 (G. Hunt ed. 1912).

3 U.S. Const. art. I, \& 8, cl. 3.

1 The Supreme Court established early that, without waiting for Congress to act, the judiciary should enforce the commerce clause as a constitutional limit on state power to interfere with interstate commerce. The judicial enforcement role rests on logical, historical, and practical assumptions. Logically, the delegation of the commerce power to Congress deprived the states of constitutional power to regulate commerce. See, e.g., Gibbons v. Ogden, 22 U.S. (9 Wheat.) 1, 197-200, 209 (1824) (Marshall, C.J.) (dictum). With the prominent exception of Chief Justice Taney, who "flatly denied that the mere grant of the commerce power operated to limit state power," F. Frankpurter, The Commzrce Clause Under Marshald, TANEY and Watte 50 (1937), the focus of debate was not whether the states were constitutionally limited, but how much. After Cooley v. Board of Wardens, 53 U.S. (12 How.) 299 (1851), settled that the commerce clause ousts state power if the subject of regulation is national in nature, but not if the subject is local, "there was distinctly a job for the courts to do." Dowling, Interstate Commerce and State Power, 27 VA. L. REv. 1, 5 (1940).

Historically, a prime reason for calling the Constitutional Convention was to deal with widespread commercial warfare among the states. Justice Johnson, concurring in Gibbons v. Ogden, 22 U.S. (9 Wheat.) 1, 226 (1824), asserted that as a result of the Convention's adoption of a centralized power to regulate commerce, "[b]y common consent," and without any need for congressional action or state repeal, state regulations of interstate commerce antedating the Constitution, "dropped lifeless from their statute books, for want of the sustaining power, that had been relinquished to Congress." See also H.P. Hood \& Sons, Inc. v. Du Mond, 336 U.S. 525, 533-34 (1949).

Finally, judicial enforcement of the "dormant" or "unexercised" commerce clause is justified by the superior ability of courts, as compared with Congress, to evaluate state commercial regulations in operation and by the realization that Congress's inability to review (for lack of time and inclination, given other priorities) every state regulation affecting interstate commerce would, if the courts did not intervene, place "the inertia of government ... heavily on the side of the centrifugal forces of localism." Brown, The Open Economy: Justice Frankfurter and the Position of the Judiciary, 67 YALE L.J. 219, 222 (1957) (footnote omitted).

- When applying the commerce clause, the Supreme Court will strike down a state law adversely affecting interstate commerce unless it satisfies two requirements. First, in order to ensure free trade among the states, state laws may not discriminate against interstate trade unless "nondiscriminatory alternatives adequate to preserve the local interests at stake" are unavailable. Hunt v. Washington State Apple Advertising Comm'n, 432 U.S. 333, 353 (1977). See also Hughes v. Oklahoma, 441 U.S. 322 (1979); Dean Milk Co. v. City of 
rectly. It explicitly prohibited state discrimination against the citizens of other states by providing that " $[t]$ he Citizens of each State shall be entitled to all Privileges and Immunities of Citizens in the several States."

The language of "citizenship" in the privileges and immunities clause has at times obscured the common concern of that clause and the antidiscrimination portion of the commerce clause with the problem of state discrimination against individuals or businesses domiciled in one of the other states. Although nonresidents have always been able to invoke the commerce clause to attack state discrimination in favor of resident interests, ${ }^{7}$ classifications on the basis of state of "residence" have sometimes escaped examination under the privileges and immunities clause on the theory that only classifications on the basis of state of "citizenship" were covered..$^{8}$ The distinction never had any real substance, ${ }^{\circ}$ particu-

Madison, 340 U.S. 349 (1951). This amounts to a virtually per se rule of invalidity for state laws favoring local commercial interests over out-of-state businesses. See City of Philadelphia v. New Jersey, 437 U.S. 617, 624 (1978); Boston Stock Exch. v. State Tax Comm'n, 429 U.S. 318, 336 (1977). In the latter case, Justice White, writing for a unanimous Court, said: The prohibition against discriminatory treatment of interstate commerce follows inexorably from the basic purpose of the Clause. Permitting the individual States to enact laws that favor local enterprises at the expense of out-of-state businesses "would invite a multiplication of preferential trade areas destructive" of the free trade which the Clause protects.

Id. at 329 (quoting Dean Milk Co. v. City of Madison, 340 U.S. 349, 356 (1951)).

Second, even nondiscriminatory state laws must not unduly burden commerce. The Court's general approach to the "burden" criterion is set forth in Pike v. Bruce Church, Inc., 397 U.S. 137, 142 (1970) (citation omitted):

Where the statute regulates evenhandedly to effectuate a legitimate local public interest, and its effects on interstate commerce are only incidental, it will be upheld unless the burden imposed on such commerce is clearly excessive in relation to the putative local benefits. . . . If a legitimate local purpose is found, then the question becomes one of degree. And the extent of the burden that will be tolerated will of course depend on the nature of the local interest involved, and on whether it could be promoted as well with a lesser impact on interstate activities.

For a comprehensive analysis disapproving judicial enforcement of the burden standard, but approving and refining judicial enforcement of the antidiscrimination criterion, see Tushnet, Rethinking the Dormant Commerce Clause, 1979 WIs. L. REv. 125.

- U.S. ConsT. art. IV, \& 2, cl. 1.

" E.g., cases cited notes 14-15 infra. The commerce clause embraces all interstate trade relationships without regard to the nature of the persons or entities involved at either end of the interstate transaction. As the Court said in Paul v. Virginia, 75 U.S. (8 Wall.) 168, 183 (1869): "The language of the [commerce clause] makes no reference to the instrumentalities by which commerce may be carried on; it is general, and includes alike commerce by individuals, partnerships, associations, and corporations."

E.g., Douglas v. New York, N.H. \& H.R.R., 279 U.S. 377 (1929); Maxwell v. Bugbee, 250 U.S. 525 (1919); La Tourette v. McMaster, 248 U.S. 465 (1919).

- As Brainerd Currie cogently argued when urging the "flat rejection" of the "idea that 
larly after the fourteenth amendment made citizens of the United States also citizens "of the State wherein they reside."10 In recent years, the Supreme Court has found citizenship and residence classifications " 'essentially interchangeable' . . . for purposes of analysis of most cases under the Privileges and Immunities Clause."11 Joint treatment of these two clauses is appropriate, therefore, because each imposes limits on state authority to discriminate on the basis of state residence.

In addition to having been a part of the Constitution since its adoption, each clause has a separate history of judicial enforcement of the principle barring discrimination on the basis of state residence. ${ }^{12}$ Even accounting for the occasional divergence of the concepts of residence and citizenship, ${ }^{13}$ therefore, it is surprising that we are still at the threshold of understanding when a state should be able to provide its own residents with advantages denied to nonresidents. The principle, like most principles of constitutional law, is not absolute. It cannot be, for fulfillment of the fundamental obligation of state government-to care for the state's own residents-depends, to some ill-defined degree, on the ability to withhold from others what a state chooses to provide to its own. As a result, there is a need to accommodate the interstate equality principle and the demands of local obligation in a way that respects the legitimate claims of each. Though the problem is simply

the clause does not reach discrimination couched in terms of residence," Currie \& Schreter, Unconstitutional Discrimination in the Conflict of Laws: Privileges and Immunities, 69 Yale L.J. 1323, 1347 (1960), reprinted in B. CuRRIE, Selected Essays ON THE Conrlict or Laws 445, 473 (1963): "In the typical state the overwhelming majority of residents are also citizens . . . and so the general tendency and effect [of a discriminatory statute is] to accomplish a discrimination in favor of local citizens and against citizens of other states." Id. at 1344, reprinted in B. CURRIR, supra, at 469 . See generally id. at 1343-49, reprinted in B. CurRIE, supra, at 468-75.

10 U.S. ConsT. amend. XIV, § 1, cl. 1 provides: "All persons born or naturalized in the United States and subject to the jurisdiction thereof, are citizens of the United States and of the State wherein they reside." As a result, discrimination against those who reside in other states is virtually identical with discrimination against citizens of other states whenever the state's concept of "residence" coincides with that of the fourteenth amendment.

11 Hicklin v. Orbeck, 437 U.S. 518, 524 n.8 (1978) (quoting Austin v. New Hampshire, 420 U.S. 656, 662 n.8 (1975)).

12 "Residence" in this sense is equivalent to "domicile"--the one state with which an individual or business is most closely connected. See generally Reese \& Green, That Elusive Word, "Residence," 6 VAND. L. RBv. 561 (1953).

13 Some "residence" distinctions were struck down after plenary review under article IV even during the very period that other distinctions on the basis of residence were held immune from review. E.g., Travis v. Yale \& Towne Mfg. Co., 252 U.S. 60 (1920); Blake v. McClung, 172 U.S. 239 (1898). 
stated, developing criteria to separate allowable from forbidden distinctions between residents and nonresidents is a formidable task.

The prime area of uncertainty is the distribution of the public resources, opportunities, and benefits available within each state. The states generally are prohibited from giving their own residents preferential access to the benefits of the state's private sector. Thus, under the commerce clause, the states may not impose restrictions granting in-state consumers either the exclusive right, or even priority, to purchase commodities produced or obtained within the state's private sector. ${ }^{14}$ Nor may the states reserve the purchasing power of resident private consumers for the advantage of resident business by denying nonresident business an equal chance to compete for the resident consumers' dollars. ${ }^{15}$ Similarly, the privileges and immunities clause guarantees an inhabitant of one state a right to the same access to private sector employment in any other state as that state's inhabitants possess, whether the employment is in an interstate or a purely local business. ${ }^{16} \mathrm{Fur}$ thermore, that clause guarantees against state infringement the right of the inhabitants of one state, when in another, to hold property ${ }^{17}$ and, presumably, to purchase from local private enterprise on equal terms with local residents. ${ }^{18}$

14 E.g., H.P. Hood \& Sons, Inc. v. Du Mond, 336 U.S. 525 (1949); Pennsylvania v. West Virginia, 262 U.S. 553 (1923); West v. Kansas Natural Gas Co., 221 U.S. 229 (1911).

16 E.g., Baldwin v. G.A.F. Seelig, Inc., 294 U.S. 511 (1935). See also Hunt v. Washington State Apple Advertising Comm'n, 432 U.S. 333 (1977); Polar Ice Cream \& Creamery Co. v. Andrews, 375 U.S. 361 (1964).

16 E.g., Hicklin v. Orbeck, 437 U.S. 518 (1978); Mullaney v. Anderson, 342 U.S. 415 (1952); Toomer v. Witsell, 334 U.S. 385 (1948); Ward v. Maryland, 79 U.S. (12 Wall.) 418 (1871).

${ }^{17}$ E.g., Blake v. McClung, 172 U.S. 239 (1898). The seminal case of Corfield v. Coryell, 6 Fed. Cas. 546, 552 (C.C.E.D. Pa. 1823) (No. 3230), included the right "to take, hold, and dispose of property" among those "fundamental" rights protected by the privileges and immunities clause, and the Court has continued to make that assumption ever since. See, e.g., Baldwin v. Fish \& Game Comm'n, 436 U.S. 371, 387 (1978); Ward v. Maryland, 79 U.S. (12 Wall.) 418, 430 (1871); Paul v. Virginia, 75 U.S. (8 Wall.) 168, 180 (1869). See generally Meyers, The Privileges and Immunities of Citizens in the Several States (pt. 2), 1 Mrch. L. REV. 364, 367-73 (1903). The place of the "fundamental" rights notion in privileges and immunities doctrine is discussed in text at notes 88-118 infra.

18 Although a majority of the Court recently upheld a residence-discriminatory license fee to hunt elk for sport in Baldwin v. Fish \& Game Comm'n, 436 U.S. 371 (1978), Chief Justice Burger went out of his way to emphasize in a concurring opinion that the

Court does not hold that the Clause permits a State to give its residents preferred access to recreational activities offered for sale by private parties. . . . The Clause assures noncitizens the opportunity to purchase goods and services on the same basis as 
When the distribution of public sector resources is at issue, however, several difficult questions remain unsettled. Some, but not all, public benefits can be reserved for the exclusive or preferential use of the state's inhabitants. The task of separating which can and cannot be reserved poses impressive obstacles. The complexity of the problem can best be revealed by a series of illustrative questions: If a state may exclude nonresidents from elementary and secondary public schools, may it also exclude them from public institutions of higher education or public hospitals? Even if it may not deny access entirely, may a state charge a nonresident more for these services than it charges residents? May a state exclude nonresidents entirely from, or charge them more for, the use of the state's courts, public parklands, public highways, or public transportation systems? If not, why are nonresidents not entitled to equal, or even any, access to welfare payments or public housing? Is denial of nonresident eligibility for state employment more troublesome than denial of eligibility for welfare benefits? If a state-run business may, consistently with the commerce clause, prefer in-state customers when it sells products manufactured from raw materials, ${ }^{19}$ does it follow that a state may prefer resident customers if the state owns and distributes valuable natural resources such as oil and gas? Finally, why is the Court equally clear that state tax and regulatory schemes violate the commerce clause if they deprive out-of-state businesses of competitive advantages they may possess over in-state competitors, and that state subsidy programs that extend eligibility to in-state businesses only, and may thereby reduce out-of-state competitive advantages to the same degree, are totally consistent with the commerce clause? ${ }^{20}$

The Supreme Court has never settled on a general theory of state citizenship that would serve to separate those publicly provided benefits belonging peculiarly to state residents and those to which nonresidents must be accorded equal access. The Court has, on rare occasion, spoken of the existence of "general" and "special" claims of state citizenship ${ }^{21}$ to signify where state obligations of equal treatment for nonresidents do and do not extend, but it

citizens; it confers the same protection upon the buyer of luxury goods and services as upon the buyer of bread.

Id. at 394 .

19 The Supreme Court recently held that it could. Reeves, Inc. v. Stake, 447 U.S. 429 (1980).

${ }^{20}$ See text at notes 194-206 infra.

21 McCready v. Virginia, 94 U.S. 391, 396 (1877), discussed in text at notes 26-31 infra. 
has not developed any general theory that would give content to those distinctions. Instead, it has developed some partial doctrines governing the accommodation of interstate equality and local obligation in a limited range of contexts.

This article attempts to develop the substantive principles that should define the proper scope of state authority to favor state residents in the distribution of public resources. The article first traces the relevant Supreme Court doctrines and demonstrates their inadequacies. Part I examines the persistent hold of the distinction between the state as regulator and the state as proprietor, in both privileges and immunities doctrine and commerce clause doctrine, as well as the current privileges and immunities doctrine that rests application of the clause on whether or not the privilege or immunity claimed is fundamental. Finding these doctrines inadequate to cope with the complexity of the problem, Part II offers an alternative approach that takes full account of both the Constitution's recognition of the states as separate, semiautonomous political communities, and the interstate equality objectives of the commerce and privileges and immunities clauses. The contemplated purposes and powers of state government and the aims of interstate equality are sometimes inconsistent. Part II therefore explores the reasons behind the general principle against residence discrimination, develops a theory of state "citizenship" to demonstrate when a state's favoritism towards its own residents is presumptively justified despite that principle, and suggests and evaluates some special factors that appear to call for adherence to the norm of interstate equality even in cases where there otherwise would be a prima facie justification for preference of state residents. With that theoretical framework in mind, Parts III and IV examine in some detail the constitutionality of state resident preference policies as applied to the distribution of a wide range of public resources. Finally, Part $\mathrm{V}$ addresses the role of Congress and asks, on the one hand, how far Congress can go in depriving the states of power to confer exclusive benefits or preferences on their residents, and, on the other, how far it can go in authorizing state discrimination against nonresidents where the states alone would not have that power.

The agenda is long, and the difficulties of the subject should not be underestimated. Every issue of state resident preference, especially in the public sector, is simultaneously an issue of discrimination and an issue of federalism. All of the subtleties of equal protection doctrine are present. The invidiousness of the classify- 
ing trait, the nature of the interests affected by the classification, and the justifications offered to support the use of the classification-all are necessarily in question here. ${ }^{22}$ In addition, assessment of those criteria in the context of residence classifications requires consideration of the role of state government within the federal union, the nature of the relationships between the states and their residents and between the states and nonresidents, and the importance of good relations among the states. Constitutional issues of interstate equality thus reflect a number of the most difficult features of constitutional law. Any effort to develop appropriate principles to govern this relatively neglected area of the law should attempt to give each feature its due and should, therefore, be sensitive both to the character of state "citizenship" and to the imperatives of interstate equality. That is the basic premise of the effort that follows.

\section{Supreme Court Doctrine: An Analysis and Critique}

\section{A. The Significance of State Ownership}

The concepts of property and autonomy are fundamentally linked in our constitutional order. Rights in property signify a range of choice in the owner's use of that property, including choices about whom to admit and whom to exclude in its distribution or use. Because of the hold of these traditional assumptions, there is an understandable temptation to treat government ownership as though it should be accompanied by a freedom of choice with respect to the property owned similar to that accompanying private ownership. As a consequence, our law, including our constitutional law, is filled with doctrines that distinguish exertions of government power through compulsory regulation or taxation from governmental exercises of power through "proprietary choice."2s

This is not to say that the Supreme Court has always allowed government the same degree of freedom in proprietary choice as it has allowed individuals. Nor do I mean to imply that the Court has

${ }^{22}$ In Dunn v. Blumstein, 405 U.S. 330, 335 (1972), for example, Justice Marshall said for the Court: "To decide whether a law violates the Equal Protection clause, we look, in essence, to three things: the character of the classification in question; the individual interests affected by the classification; and the governmental interests asserted in support of the classification."

ss For a comprehensive discussion of the doctrinal uses of the distinction, see Wells \& Hellerstein, The Governmental-Proprietary Distinction in Constitutional Law, 66 VA. L. REv. 1073 (1980). 
uncritically accepted analogies designed to reserve for government the same degree of autonomy that is recognized for private proprietors. For example, the immunity private proprietors would possess, absent civil rights legislation, to discriminate in their business dealings on racial or other invidious grounds would certainly not extend to government. ${ }^{24}$ Furthermore, the Court sometimes questions whether a form of government conduct claimed to be proprietary can fairly be characterized as such. ${ }^{25}$ But for all of this, it is nonetheless true that the proprietary concept has had a recurring, if erratic, influence on the Court's willingness to sanction government actions it might otherwise condemn. Nowhere is this more true than in the history of Supreme Court decisions under the commerce clause and the interstate privileges and immunities clause.

The purpose of this section is to evaluate the use of the proprietary/regulatory distinction in those settings. In the course of that evaluation, it will become clear that the grasp of the proprietary idea has been tenacious but uncertain. In light of the Court's ambivalence toward proprietary power, a number of questions arise. Is the distinction grounded in a meaningful set of constitutional values? Do the usual sources of constitutional interpretation compel or even suggest its use? To what degree does it clarify or obscure analysis? Finally, should the distinction be modified or abandoned?

1. The Proprietary Idea and the Privileges and Immunities Clause. Three decisions of the Supreme Court involving nonresident access to natural resources illustrate the uncertain place of the proprietary idea in privileges and immunities doctrine. In $M c$ Cready v. Virginia, ${ }^{26}$ the post-Civil War Supreme Court upheld state power to forbid nonresidents from planting oysters in state-

${ }^{24}$ See The Civil Rights Cases, 109 U.S. 3, 24-25 (1883). Compare Shelley v. Kraemer, 334 U.S. 1, 13 (1948) (dictum) (no violation of the fourteenth amendment for private owners to adhere voluntarily to an agreement to refuse to sell to blacks) with Burton v. Wilmington Parking Auth., 365 U.S. 715, 723-24 (1961) (even though refusal of a purely private restaurant to serve blacks would not violate fourteenth amendment, refusal of service by a privately owned restaurant leasing a portion of a state-owned building otherwise devoted to public business would).

${ }^{2 s}$ E.g., Hicklin v. Orbeck, 437 U.S. 518, 528-31 (1978). Compare Southeastern Promotions Ltd. v. Conrad, 420 U.S. 546, 555-56 (1975) (Blackmun, J.) (state ownership of theater does not change its nature as a public forum and hence does not justify censorship) with id. at 570-74 (Rehnquist, J., dissenting) (state can control use of its theater in nondiscriminatory fashion).

2* 94 U.S. 391 (1877). 
owned tidelands. Chief Justice Waite said that the valuable right to share in the use of Virginia's tidebeds was "in fact, a property right, and not a mere privilege or immunity of citizenship," that the citizens of Virginia, "and they alone, owned the property to be sold or used, and they alone had the power to dispose of it as they saw fit." 28 The Court did not doubt that Virginia was constitutionally restricted in imposing more burdensome conditions on the pursuit of a livelihood in Virginia by citizens of other states than on similar activities by its own citizens. Rather, it assumed that a state, like any other owner, could grant to whomever it chose "the exclusive use of a part of the common property."29 Just as a private owner in Virginia might choose not to deal with nonresidents, so could the state reserve its property for its own citizens without impairing a privilege or immunity of "general" as opposed

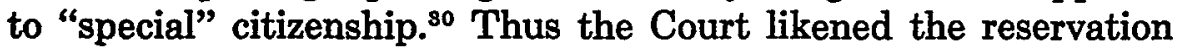
of Virginia tideland for the use of Virginia citizens to the distribution to residents only of the proceeds of sales of state land and to the assumed right of the state as landlord to restrict the rental of state land for planting corn to residents alone. ${ }^{31}$

Just after World War II, a very different Supreme Court took a very different view of a claim of state proprietary power to exclude nonresidents. Toomer $v$. Witsell, ${ }^{32}$ the high-water mark of the doctrine of interstate equality in the Supreme Court, held invalid, under the privileges and immunities clause, South Carolina's attempt to charge nonresidents 100 times more than residents for a license to pursue migratory shrimp found in the state's coastal waters. ${ }^{33}$ The Court rejected the argument that South Carolina had a property interest in the shrimp that justified the discrimination. Although Chief Justice Vinson characterized McCready in unflattering terms, ${ }^{34}$ he ultimately distinguished the two cases on the

27 Id. at 395.

${ }^{28}$ Id. at 396.

s? Id.

so Id.

s1 Id. at 395-96.

32334 U.S. 385 (1948).

ss Although the degree of discrimination against nonresidents in Toomer was dramati-

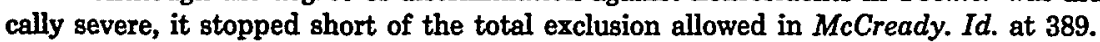

st He described $\mathrm{McCready}$ as the only case where the "Court actually upheld State action discriminating against commercial fishing or hunting by citizens of other States where there were advanced no persuasive independent reasons justifying the discrimination," id. at 400; he said that "[h]owever satisfactorily the ownership theory explains ... McCready," it was distinguishable, id. at 401; and he concluded that "the McCready excep- 
ground that South Carolina's interest in shrimp was much less of an "ownership" interest than Virginia's interest in its tidelands. As free-swimming creatures that migrate along the Atlantic seaboard, shrimp that have not been reduced to possession could not easily be said to belong to South Carolina just because they were sometimes known to be in the ocean bordering that state. ${ }^{35}$ Moreover, the Court had earlier held in United States $v$. California ${ }^{36}$ that "neither the thirteen original colonies nor their successor States separately acquired 'ownership' of the three-mile belt."s7 Having concluded that South Carolina did not own either the shrimp or the sea in which they could be found, Chief Justice Vinson then took a (perhaps unnecessary) step further and maintained that the "whole ownership theory, in fact, is now generally regarded as but a fiction expressive in legal shorthand of the importance to its people that a State have power to preserve and regulate the exploitation of an important resource."38

Toomer's begrudging treatment of $\mathrm{McCready}$ left the continuing vitality of the proprietary "exception" to the privileges and immunities clause uncertain. So does the current Court's unanimous decision in Hicklin $v$. Orbeck, ${ }^{39}$ which rejected the claim of Alaska that, as owner of substantial oil and gas deposits within the state, it could require private employers extracting or piping oil and gas under arrangements with the state, as well as businesses providing support services, to hire Alaska residents in preference to nonresidents for in-state work. The Court squarely refused to "agree that the fact that a State owns a resource, of itself, completely removes a law concerning that resource from the prohibitions of the Privileges and Immunities Clause." 0 Instead, state ownership "is a factor-although often the crucial factor-to be considered in evaluating whether the statute's discrimination against noncitizens violates the Clause." $"$ In Hicklin, the factor of ownership was not dispositive, because

tion to the privileges and immunities clause, if such it be, should not be expanded to cover this case," id. at 402.

as Id. at 401.

s6 332 U.S 19 (1947).

s7 Toomer v. Witsell, 334 U.S. 385,402 (1948).

ss Id. Toomer did recognize that some discriminatory conduct would not be barred by the privileges and immunities clause. For the test it developed, see note 94 infra.

so 437 U.S. 518 (1978).

10 Id. at 528.

1 Id. at 529 . 
Alaska has little or no proprietary interest in much of the activity swept within the ambit of Alaska Hire [the residentpreference statute]; and the connection of the State's oil and gas with much of the covered activity is sufficiently attenuated so that it cannot justifiably be the basis for requiring private employers to discriminate against nonresidents. ${ }^{42}$

The Court based this finding on the application of Alaska Hire "to employers who have no connection with the State's oil and gas, perform no work on state land, have no contractual relationship with the State, and receive no payment from the State."4s

Perhaps the most that can be said about state proprietary power over natural resources is (1) that the privileges and immunities clause grants no exception from the normal antidiscrimination rule when a state has no greater claim to ownership than a regulatory power over in-state resources possessed by no one; and (2) when a state's claim of ownership conforms more closely to traditional forms of private ownership, some undefined proprietary interest gives the state somewhat greater power than it would otherwise have to discriminate against the citizens of other states, but not complete immunity from scrutiny. In light of Toomer's criticism of the ownership theory and Hicklin's acknowledgment of the importance of ownership while simultaneously rejecting the proprietary claim, we do not know whether McCready would be followed today." We do not know whether Alaska could have required only those businesses with whom it contracted directly to give Alaskans job preference, or even whether Alaska could have refused to deal with businesses owned by nonresidents when it granted exploitation rights. ${ }^{45}$ Nor can we speculate with much confidence about what the answers to these important questions would be, for we do not know either the nature or the extent of a state proprietary interest that the Court would perceive as a legitimate justification of resident preference. We know only that a state is assumed to share some undefined portion of the autonomy possessed by private proprietors. In the privileges and immunities cases, the Court has never attempted to analyze whether the reasons that support the

42 Id.

43 Id. at 530.

4 Compare Hellerstein, Hughes v. Oklahoma: The Court, The Commerce Clause, and State Control of Natural Resources, 1979 Sur. CT. REv. 51, 86-90 (arguing that McCready might be followed) with text at notes 239-241 infra (exclusion of nonresidents not justified).

48 For my view of these questions, see text at notes 253-254 infra. 
freedom of disposition granted private property owners give equal support to state freedom to dispose of public property, or what other feature of state ownership might justify departure from the interstate equality principle.

2. The Relationship Between the Privileges and Immunities Clause and the Commerce Clause. Given the common origin and overlapping objectives of the privileges and immunities clause and the commerce clause, it is not surprising that the Supreme Court has at various times responded to proprietary claims in a similar manner, irrespective of which of these two clauses was in issue. Experience with the proprietary concept under the commerce clause is more varied, however, and provides a better opportunity to evaluate the regulatory/proprietary distinction. Before undertaking that assessment, however, a brief comparison of the ways in which the two clauses differ will help clarify the nature of the issues arising under each.

Most commentators discussing the differences in the operative scope of the two clauses ${ }^{48}$ stress the Court's holding that corporations are not within the category of "citizens" protected by article IV, section $2^{47}$ and the Court's dicta that aliens also are excluded from the protection of that clause, ${ }^{48}$ while noting that the commerce clause is not so limited. But looking at what activities are covered by the two clauses, rather than who is entitled to claim their protection, reveals more about the Court's focus in deciding the substantive validity of state conduct challenged as discriminatory. At the most elementary level, the primary concern of the commerce clause is business that involves more than one state, whereas the core concern of the interstate privileges and immunities clause is the treatment received within a state by the citizens of other states. If New York were to forbid the sale of milk pro-

18 E.g., J. Nowak, R. Rotunda \& J. Young, HandBook on Constitutional Law 276 (1978); L. Tribe, American Constitutional Law § 6-33, at 411 (1978).

${ }^{47}$ E.g., Paul v. Virginia, 75 U.S. (8 Wall.) 168, 177-82 (1869); Bank of Augusta v. Earle, 38 U.S. (13 Pet.) 519, 586 (1839). The notion that corporations are not "citizens" for purposes of the privileges and immunities clause is more venerable than sound. It is, after all, people who do business in the corporate form, and the underlying antidiscrimination objectives of the clause can be thwarted as much by state discrimination against businesses incorporated in other states as by state discrimination against natural persons who make their homes in other states.

1s E.g., Blake v. McClung, 172 U.S. 239, 247 (1898) (semble); Paul v. Virginia, 75 U.S. (8 Wall.) 168, 177 (1869) (semble); Scott v. Sandford, 60 U.S. (19 How.) 393, 419 (1857). For a full discussion of the constitutional limits on state discrimination against aliens who live in other states, see note 162 infra. 
duced in New York to firms operating outside the state, the Court would rely on the antidiscrimination portion of the commerce clause to strike down the regulation, regardless of whether those firms were owned by out-of-staters or by New Yorkers. ${ }^{49}$ If New York were to forbid residents of other states to purchase milk in New York for consumption there, the privileges and immunities clause would provide a ready weapon to strike down the discrimination..$^{50}$ Perhaps the commerce clause could also be pressed into service in the latter case, because it protects personal interstate movement and the consumption ban might be held an infringement on that right. But the very statement of the reasoning that would have to be adopted indicates how much more appropriately the privileges and immunities clause could be applied.

Differentiating the core concerns of the two clauses helps in clarifying the position of some of the Justices who have been asked to gauge the validity of a challenged state policy and in measuring the persuasiveness of their positions. In Toomer $v$. Witsell, for example, Justice Frankfurter thought the majority had misapplied the privileges and immunities clause, but he concurred in the result on the basis of the commerce clause. Whether or not South Carolina's interest in the shrimp technically could be described as an "ownership" interest, he believed the state could reserve them for capture and local consumption by its own people. ${ }^{51}$ The scheme violated the commerce clause, however, because South Carolina instead sought to reserve for its own residents the business of exporting shrimp in interstate commerce. ${ }^{62}$ The significance of the majority's decision to rest the case on the privileges and immunities clause, then, was that nonresident fishermen, whether they operated in interstate commerce or restricted their business activity to catching and selling shrimp entirely within South Carolina's borders, had to be treated on a par with South Carolina fishermen. The commuter who works in a neighboring state in a business engaged in wholly intrastate commerce is thus protected by the privi-

49 See, e.g., H.P. Hood \& Sons, Inc. v. Du Mond, 336 U.S. 525 (1949).

so See Baldwin v. Fish \& Game Comm'n, 436 U.S. 371, 394 (1978) (Burger, C.J., concurring).

s1 334 U.S. at 408. It seems clear from Justice Frankfurter's approval of McCready that he thought the state could reserve for residents both the consumption of locally caught shrimp and the livelihood of catching the shrimp locally, although it would certainly be possible to recognize a right to prevent all exportation while allowing nonresidents to catch and sell shrimp locally.

${ }^{82}$ Id. at 409. 
leges and immunities clause against the neighboring state's discrimination in favor of its own residents.

A similar focus on the separable concerns of the commerce and the privileges and immunities clauses reveals an important weakness in the dissenting opinion of Justice Rehnquist in Hughes $v$. Oklahoma. ${ }^{53}$ The majority struck down, as a violation of the commerce clause, an Oklahoma statute forbidding the out-of-state shipment for sale of minnows caught in state waters. Justice Rehnquist argued, in part, that there was no discrimination against outof-state enterprises in favor of local businesses because this was "not a case where a State's regulation permits residents to export naturally seined minnows but prohibits nonresidents from so doing." 54 Although the argument would be relevant to a privileges and immunities claim, the statute's "evenhanded application" as between residents and nonresidents does not support the claim that it does not discriminate against interstate commerce. The fact remains that the statute sought to embargo minnows for intrastate sale only. It was therefore a classic illustration of a law discriminating against interstate commerce by excluding from interstate commerce altogether a commodity available for intrastate commerce.

3. The Proprietary Idea and the Commerce Clause. Hughes v. Oklahoma also represents the current Supreme Court view of the claim that state "proprietary interests" in wildlife permit discriminations against interstate commerce that would clearly be impermissible if applied to interstate sales of privately owned goods. Not too long after $\mathrm{McCready}$ seemed to create a proprietary exception to the interstate equality principle of the privileges and immunities clause, Geer $v$. Connecticut ${ }^{58}$ did the same for the commerce clause. Geer upheld an absolute ban on the out-of-state shipment of game birds lawfully killed within the state by relying on "the principle of common ownership," which included state freedom to keep the property within the state. The Court apparently recognized that the state autonomy derived from common ownership of wildlife within the state differed from individual freedom to deal with private property, in that

s3 441 U.S. 322, 339 (1979).

st Id. at 344 .

ss Id.

se 161 U.S. 519 (1896).

${ }^{87} I d$. at 526. 
the power or control lodged in the State, resulting from this common ownership, is to be exercised like all other powers of government, as a trust for the benefit of the people, and not as a prerogative for the advantage of the government, as distinct from the people, or for the benefit of private individuals as distinguished from the public good..$^{58}$

Nonetheless, the Court used the fact of common ownership to justify embargoes of wild game without permitting embargoes of privately owned commodities.

But the recognition that state freedom to control public property differed in character from private freedom to control private property carried the seeds of Geer's destruction. When Louisiana tried to force the relocation of the shrimp packing industry by declaring the uncaught shrimp in Louisiana waters to be state property and by withholding from those who caught them the property right to export shrimp meat unless the heads and hulls were removed in Louisiana, the Court, in Foster-Fountain Packing Co. $v$. Haydel, ${ }^{58}$ was able to distinguish Geer. The ground for the distinction was that a state that retains animal life for local consumption is acting "in its sovereign capacity as representative of the people," interstate commerce necessarily "put[s] an end to the trust upon which the State is deemed to own or control the [wildlife] for the benefit of its people." ${ }^{\text {"11 }}$ As a necessary result, said Justice Butler, those who capture wildlife that a state does not withhold entirely from interstate commerce "become entitled to the rights of private ownership and protection of the commerce clause."162

Geer's destruction was completed by Hughes. After Toomer described the wildlife ownership theory as a "fiction," it was but a small step for the Court in Hughes to overrule Geer and find that the usual criteria of commerce clause analysis should apply to the regulation of wildlife, just as they apply to the regulation of goods in private possession. Together, Foster-Fountain and Geer had created the anomaly of a state possessing greater power to prevent interstate shipment of wildlife completely than to limit the condi-

\footnotetext{
ss Id. at 529.

s9 278 U.S. 1 (1928).

${ }^{\circ}$ Id. at 11 .

i1 Id. at 13.

82 Id.
} 
tions under which interstate shipment might take place. ${ }^{63}$ It was time to recognize, as the Court already had under the privileges and immunities clause, that even if state ownership might sometimes permit greater freedom to control the disposition of property, only actual state ownership, and not fictional claims of community control that in fact amount to regulation more than ownership, could qualify.

But the proprietary exception to the antidiscrimination principle of commerce clause doctrine persists in other forms. Following the lead of several state court cases, ${ }^{64}$ on three recent occasions the Supreme Court has upheld state purchasing and selling policies that discriminate in favor of in-state business. Generally, if a state interferes with private sector market choices through tax or regulatory schemes whose purpose is to favor in-state business to the relative disadvantage of out-of-state business, or that use residencediscriminatory means to accomplish otherwise permissible ends, the Court applies a "virtually per se rule of invalidity." When, however, the state itself is buying or selling, instead of interfering with the buying or selling decisions of private parties in the interstate market, the Court has generally refused to apply either the nondiscrimination rule or the rule that even nondiscriminatory state programs must not unduly burden interstate commerce. ${ }^{\text {BB }}$

es 441 U.S. at 335.

ot E.g., City of Phoenix v. Superior Court, 109 Ariz. 533, 514 P.2d 454 (1973); Schrey v. Allison Steel Mfg. Co., 75 Ariz. 282, 255 P.2d 604 (1953); City of Denver v. Bossie, 83 Colo. 329, 266 P. 214 (1928); In re Gemmill, 20 Idaho 732, 119 P. 298 (1911); People ex rel. Holland v. Bleigh Constr. Co., 61 Ill. 2d 258, 335 N.E.2d 469 (1975); State ex rel. Collins v. Senatobia Blank Book \& Stationery Co., 115 Miss. 254, 76 So. 258 (1917); Allen v. Labsap, 188 Mo. 692, 87 S.W. 926 (1905); Hersey v. Nelson, 47 Mont. 132, 131 P. 30 (1913); Tribune \& Binding Co. v. Barnes, 7 N.D. 591, 75 N.W. 904 (1898).

os City of Philadelphia v. New Jersey, 437 U.S. 617, 624 (1978) (regulation); Boston Stock Exch. v. State Tax Comm'n, 429 U.S. 318, 336 (1977) (taxation).

- For a brief discussion of these two rules, see note 5 supra. The Court has not accepted the fact of state ownership alone as justifying a state's discrimination against nonresidents. In South Carolina State Highway Dep't v. Barnwell Bros., Inc., 303 U.S. 177 (1938), the Court did place some emphasis upon state ownership of state highways when it rejected the claim that a law setting maximum weight and width limits for trucks using those highways unduly burdened interstate commerce. Justice Stone emphasized that "[u]nlike the railroads, local highways are built, owned and maintained by the state or its municipal subdivisions." Id. at 187. But even on that assumption, he made plain that the burden was permissible only "so long as the state action does not discriminate," id. at 189, for the "commerce clause, by its own force, prohibits discrimination against interstate commerce, whatever its form or method," $i d$. at 185. Explaining the ban on discrimination, Justice Stone wrote that "when the regulation is of such a character that its burden falls principally upon those without the state, legislative action is not likely to be subjected to those political restraints which are normally exerted on legislation where it affects adversely some interests 
Thus, in American Yearbook Co. v. Askew, ${ }^{67}$ the Court, without an opinion, summarily upheld the right of a state to confine its purchases of goods and services for the operation of government to suppliers operating within the state. Later, in Hughes v. Alexandria Scrap Corp. ${ }^{68}$ the Court articulated for the first time the view that the commerce clause does not limit state proprietary decisions in the market. That case involved a Maryland subsidy program designed to stimulate the removal of cars abandoned in the state through the payment of a bonus for each "hulk" destroyed. That bonus was split between any licensed wrecker that delivered the hulk to a scrap processor and the processor itself. Thus the state was essentially either purchasing or subsidizing the removal and destruction of these hulks. An out-of-state processor challenged an amendment to the original subsidy scheme that effectively eased the bonus eligibility requirements for deliveries to in-state processors. The Court decided that the commerce clause does not even "require independent justification" for discrimination in the expenditure of state funds for the purchase, "in effect, of a potential article of interstate commerce." Justice Powell held that "[n]othing in the purposes animating the Commerce Clause prohibits a State, in the absence of congressional action, from participating in the market and exercising the right to favor its own citizens over others."70 Finally, in Reeves, Inc. v. Stake, ${ }^{71}$ the Court elevated the marketplace participation exemption to a "general rule" when it upheld South Dakota's right, as owner of a cement plant, to prefer private businesses within the state over out-ofstate businesses when selling the cement, at least when the supply could not satisfy the demand of both groups. Although admitting that the "general rule of Alexandria Scrap . . . necessarily admits of exceptions,"72 the Court nonetheless found the state preference for a state-owned enterprise's in-state customers to be a classic instance of permissible proprietary choice.

What accounts for the significant assumption that state buy-

within the state." Id. at 185 n.2. See also Raymond Motor Transp., Inc. v. Rice, 434 U.S. 429,444 n. 18 (1978).

67 409 U.S. 904 (mem.), aff'g 339 F. Supp. 719 (M.D. Fla. 1972). Justices Brennan and White voted to hear the case.

426 U.S. 794 (1976).

69 Id. at 808-09.

70 Id. at 810 (footnote omitted).

71447 U.S. 429 (1980).

72 Id. at 440 . 
ing and selling policies are generally immune from commerce clause limits that apply to state interference with interstate dealings among private buyers and sellers? In Reeves, Justice Blackmun's majority opinion offered a general defense of the "distinction ... between States as market participants and States as market regulators."73 Drawing from a variety of sources, including the state cases that had adopted the same distinction, ${ }^{74}$ Justice Blackmun provided essentially four justifications for the wider latitude afforded state proprietary activity. The first is the historical argument that the commerce clause was "principally" intended to inhibit state tax and regulatory measures "impeding free private trade in the national marketplace," leaving the "States themselves to operate freely in the free market."75 The second is a curious blend of the state's sovereign responsibilities as guardian and trustee of its people and the state's right to be just like any trader in the private sector, with the power to choose with whom to deal. ${ }^{78}$ The third is an assumed obligation of evenhandedness. Because state proprietary activities often are subject to federal taxes and regulations in the same way that private businesses are, those activities should be as immune from commerce clause restraints as private enterprise is. ${ }^{77}$ The final justification is the practical difficulty of assessing the validity of state purchasing and selling policies under traditional commerce clause criteria. ${ }^{28}$

None of these justifications will carry the day. The Framers' principal concern in fashioning the commerce clause may well have been state interference with interstate private trade. There is, however, no indication that they thought about state proprietary policy at all. If state resident preference restrictions in proprietary policy threaten the interstate unification or free-trade goals of the commerce clause, it is difficult to see why commerce clause limits would not be appropriate. Just as the extent of congressional power under the commerce clause has changed dramatically from what was consciously contemplated at the time of its adoption, so might the nature of commerce clause restrictions on state power change if the needs of interstate commerce and the disruptive effects of state action affecting interstate commerce have evolved so

\footnotetext{
73 Id. at 436. He said that the distinction "makes good sense and sound law." Id.

74 Id. at 437 n.9; see note 64 supra.

7s 447 U.S. at 437 .

7o Id. at $438-39$.

77 Id. at 439 .

3 Id.
} 
as to render disturbing what once might have been innocuous. ${ }^{79}$

Nor will the state's role as "sovereign trader" suffice to explain the regulatory/proprietary distinction. The states of course act as guardians and trustees for their people when they regulate as well as when they trade. Moreover, when they trade (and particularly when they choose to prefer residents) they are more likely than private traders to be motivated by noneconomic political influences. $^{80}$ Precisely because state proprietary activity is a blend of both private and public business, it is not sufficient to assume that the state should have the same freedom to choose business policy as private business. In fact, the differing nature of state and private proprietary interests recognized in $\mathrm{Geer}^{81}$ prevents that assumption. The very act in question-favoritism of in-state residents without regard to profit-is one that belies reliance on concepts of private property; it is a public act.

The evenhandedness rationale fares no better, for it too begs the question. Why is it important to allow state business to be conducted with the same freedom as private business? Surely the constitutional limitations imposed on states are not generally thought to be unfairly imposed simply because they are not also applied to private concentrations of power. As Paul Freund reminded us long ago, private aggregations of wealth may have as detrimental an impact on the maintenance of a national free-trade unit as state interferences with interstate commerce, and yet the commerce clause

79 The general point was well expressed by Roscoe Pound:

[T] he balance of nation and state has not remained constant. The relative political position of nation and state has shifted with the increasing economic unification of the country, with the growth of enterprises and businesses transcending state lines, and with the advent of rapid transportation and instantaneous communication. Many things that were local have become national. But it is one of the conspicuous merits of the federal constitution that, as it was drawn up before the coming of the nineteenth century tendency to govern everything by precise rule, it did not attempt detailed laying down of what was national and what local, but left the details to be settled by experience under a general principle. Thus the balance of the national and the local, characteristic of our polity, can maintain itself, since changes in relative economic importance affect the application of the principle but not the principle itself.

Pound, Law and Federal Government, in Federauism as a Democratic Process 3, 16-17 (1942). The economic significance of state proprietary discrimination is discussed in F. MELder, State and Local Barkiers to Interstate Commerce in the United States: A Study In Economic Sectionalism 12-36 (1937); Melder, The Economics of Trade Barriers, 16 Ind. L.J. 127, 139-40 (1940).

so As Justice Powell argued in dissent, a "state frequently will respond to market conditions on the basis of political rather than economic concerns." 447 U.S. at 450.

si See text at note 58 supra. 
limitation applies only to the states. ${ }^{82}$ If the reason for this different treatment is the perception that state discrimination against interstate commerce is more likely to lead to interstate friction than similar policies on the part of private business, that state and private business are equally subject to federal regulation is irrelevant to the underlying goals of the commerce clause.

Finally, the argument based on the practical difficulty of assessing state proprietary activity also is unconvincing. Subtlety, complexity, and political controversy are hardly unknown in traditional commerce clause analysis. Moreover, if the Court is prepared to weigh incommensurable values in regulatory cases, ${ }^{83}$ what is more difficult about weighing the values of legitimate proprietary choice against its impact on interstate activity? Perhaps enforcement seems more difficult because a state may just "happen to choose" resident suppliers and customers without announcing a policy of resident preference. But the Court could easily forbid overt policies of preference, because they are most likely to create interstate friction, and perhaps it might allow nonresidents to prove discrimination in practice as well. Moreover, an exception that sometimes allows departure from the "virtually per se rule" against discrimination creates its own complexity and controversy. ${ }^{84}$

More fundamental than the Court's inability to articulate sound reasons for distinguishing regulatory from proprietary activity, however, is the Court's own suggestion that the distinction is

s2 Freund, Umpiring the Federal System, 54 Colum. L. REv. 561, 563 (1954).

${ }^{83}$ Compare Raymond Motor Transp., Inc. v. Rice, 434 U.S. 429, 440-43 (1978) (Powell, J.) (weighing safety purpose of regulation against degree of interference with interstate commerce) with id. at 448-50 (Blackmun, J., concurring) (contending that the Court will not engage in such a weighing process if the asserted safety purpose is not illusory).

s For one thing, because so much rests on whether state conduct is labeled "regulatory" or "proprietary," judges sensitive to other considerations may strain to choose the desired label and reach controversial results. After Reeves, for example, a divided panel of the Fifth Circuit held that a state rule giving resident farmers a preferred right to lease from the state the most desirable sales locations at the state-owned farmers market violated the commerce clause. Smith v. Department of Agriculture, 630 F.2d 1081 (5th Cir. 1980). The majority concluded that the state was a market regulator, rather than a market participant, because it did not produce, buy, or sell the goods offered for sale in the marketplace. Id. at 1083 . The dissent deemed the state conduct clearly proprietary, however, because the transaction relevant to the contested policy was the leasing of state property, not the sale of goods by the tenants. Id. at 1087-88 (Randall, J., dissenting).

The dissent had the better of this argument. The state chose to prefer residents as renters here, just as South Dakota chose to prefer residents as purchasers in Reeves. For the view that the leasing policy should have been upheld, not because it should escape any scrutiny, but because it is justifiable favoritism, see note 224 infra. 
not necessarily determinative. ${ }^{85}$ Broad exceptions to the distinction cause one to wonder whether the distinction has meaningful content. Reeves raises the possibility of a gigantic exception to the liberal treatment of state proprietary choices by suggesting that when the state owns and disposes of natural resources, as distinct from products made from them, a policy of resident preference might indeed be subject to traditional commerce clause analysis. ${ }^{86}$ None of the Court's four justifications for treating state proprietary activity with greater deference than state taxation or regulation would support the further distinction between the state's proprietary activities as natural resource entrepreneur and as operator of any other kind of business. If there is some reason to distinguish the case of state-owned natural resources from other state-owned property, the regulatory/proprietary distinction is not it.

All this is not necessarily to say that Reeves was wrongly decided. What is striking about the Court's generalized attempt to justify the market participation exemption from usual commerce clause restrictions, however, is that it did not attempt to establish any intrinsic value for the state's freedom to choose a resident preference policy. Historical intention, comparison with the prerogatives of the private sector, and the practical difficulties of judicial review do not speak to any intrinsic attribute of state sovereignty that might make it substantively important to allow South Dakota to adopt its resident preference policy. ${ }^{87}$

ss 447 U.S. at 440.

se Id. at 443-44. This portion of the Reeves opinion is discussed in text at notes $220-223$ infra.

${ }^{87}$ In a recent article that explores the uses of the regulatory/proprietary distinction in constitutional law generally and concludes that the distinction is often used to mean different things in different contexts, Professors Wells and Hellerstein devote a portion of their discussion to its use in commerce clause doctrine. Wells \& Hellerstein, supra note 23, at 1121-35, 1139-41. In particular, they examine whether the immunity granted state proprietary choices is a way of (1) putting aside a category of state actions that affect commerce in only trivial ways, (2) protecting those state interests that truly parallel private business interests, or (3) recognizing that state autonomy to distribute state-owned resources outweighs the national interest in "unfettered commerce among the states." Id. at 1127-34.

With respect to the first explanation, Wells and Hellerstein recognize that there is no particular reason to suppose that proprietary policies affect the flow of commerce much less than regulatory policies do. Id. at 1127-28. I would add that not only has the Court never suggested that the extent of the restriction of interstate commerce, rather than its character, figures in the exemption of state marketplace activity from commerce clause scrutiny, but available indications point in the opposite direction. Justice Powell, who wrote the Court's opinion in Alexandria Scrap, dissented in Reeves. He found the cases distinguishable, because when a state bids up the price of an article of commerce, it does not burden the flow of interstate commerce, because the incentive to sell in-state is merely the higher price, 


\section{B. Fundamental Activities and the Scope of the Privileges and Immunities Clause}

\section{The Supreme Court recently attempted to define the residuum} of state power to prefer residents after the demands of insterstate equality have been satisfied. In Baldwin v. Fish \& Game Commis-

leaving an out-of-state business free to compete for the article by raising its price. When a state's marketing policy cuts off supply to out-of-state customers, however, there is no possibility for an out-of-state business to compete with its in-state competitors for the limited supply of articles to be sold. 447 U.S. at $452-53$. The majority's response in Reeves was not that the burden on commerce was minimal in both cases, but, to the contrary, that the burden in Alexandria Scrap was also substantial and that this did not matter in light of the proprietary nature of the state's conduct. Id. at 435 n.7. Furthermore, these are not just cases where the burden imposed on interstate commerce is in issue. These are classic instances of discrimination against out-of-state business, and so they would seem to be likely candidates for "per se invalidity" under the commerce clause regardless of the burden imposed.

Wells and Hellerstein also agree that the proprietary exemption cannot be justified as a means of recognizing "the government's legitimate business-like interests," because resident preference has political, not economic, objectives. 66 VA. L. REv. at 1129. They are somewhat more receptive to the state fiscal autonomy explanation. They suggest that "[i]f the cases in this area ultimately reflect the judgment that the states' interest in distributing their own resources as they see fit overrides the nation's interest in unfettered commerce among the states, then the governmental-proprietary distinction may be performing a constructive function in commerce clause analysis." Id. at 1134. They ask whether there is a better method for accommodating the state and national interests than using this distinction, and conclude that it "depends on one's view of the nature of the appropriate accommodation." Id. Thus, "[i]f . . . one has concluded as a matter of principle that the state's interest in spending its money as it sees fit will always prevail over the values protected by the commerce clause ... then reliance on the governmental-proprietary distinction as a decisional mechanism may produce satisfactory results, even if it obscures the underlying rationale for them." Id.

If one accepts the qualifications in this less-than-wholehearted endorsement of the distinction, it is difficult to disagree with the conclusion. But one can criticize the notion that state fiscal autonomy interests will "always prevail." Although the Court undoubtedly desires to protect some state autonomy to distribute state resources, that value surely is not absolute enough to justify constitutional immunity for some group of distributional choices labeled "proprietary." There is no neat division between public and private sectors that can explain a decision to leave the state free to reserve state monies, goods, and services for the exclusive benefit of state residents, but prohibit the states from treating private resources within the state in the same way. State exclusion of nonresidents from equal access to, or any use of, state highways, courts, parks and beaches, libraries, and public transportation systems, as well as state-owned natural resources, would present difficult issues that could not be glossed over by saying that, because state resource distribution policies are at issue, the commerce clause, or the privileges and immunities clause for that matter, would impose no restraint. Even though state distributional autonomy is an important value, it is necessary to understand why the autonomy exists, so that it can properly be related to the important value of limiting state power to discriminate against nonresident individuals and businesses. State interests in public resource distribution cannot be made "trumps" without offending our intuitive sense of what interstate equality requires. 
sion $^{88}$ the Court committed itself to the view that the interstate privileges and immunities clause only requires the state to treat residents and nonresidents "without unnecessary distinctions" when the nonresident seeks to "engage in an essential activity or exercise a basic right." 88 The theory behind this limitation is that, unless the right or activity is "fundamental," state discrimination against nonresidents does not "frustrate the purposes of the forma-

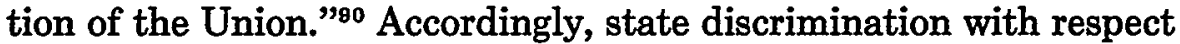
to nonfundamental activities "does not fall within the purview of the Privileges and Immunities Clause."91

In Baldwin, the Court held recreational elk hunting to be nonfundamental, ${ }^{92}$ with the result that the privileges and immunities clause did not prevent Montana from imposing on nonresidents a hunting license fee at least 7.5 times as great as the fee charged residents. ${ }^{83}$ If the sport had been held a fundamental activity, presumably the standard established in Toomer $v$. Witsell for judging the compatibility of policies disadvantaging nonresidents with the command of the privileges and immunities clause would have applied. The state would have had to show that there were substantial reasons, apart from nonresidence, for the fee differential and, further, that the degree of discrimination bore a close relation to those reasons. ${ }^{94}$ That was a showing the state could not make. ${ }^{95}$ Instead, the state was only required to justify the discrimination under the minimum rationality standard of review of the equal protection clause. That standard essentially leaves the state free to draw any distinction based on residence

\footnotetext{
88436 U.S. 371 (1978).

89 Id. at 387.

$\infty I d$.

92 Id. at 388.

92 Id.

9s The license fee scheme is described in id. at 373-74.

24 Like many other constitutional provisions, the privileges and immunities clause is not an absolute. It does bar discrimination against citizens of other States where there is no substantial reason for the discrimination beyond the mere fact that they are citizens of other States. But it does not preclude disparity of treatment in the many situations where there are perfectly valid independent reasons for it. Thus the inquiry in each case must be concerned with whether such reasons do exist and whether the degree of discrimination bears a close relation to them. The inquiry must also, of course, be conducted with due regard for the principle that the States should have considerable leeway in analyzing local evils and in prescribing appropriate cures.
}

Toomer v. Witsell, 334 U.S. 385, 396 (1948) (footnote omitted).

.5 See Bald'win v. Fish \& Game Comm'n, 436 U.S. 371, 402-05 (1978) (Brennan, J., dissenting). 
that is not totally arbitrary. ${ }^{96}$

As a method of separating permissible from impermissible resident preferences, the fundamental/nonfundamental distinction may have even less to commend it than the regulatory/proprietary distinction. To begin with, the idea that disadvantaging nonresidents more than is necessary to compensate for any peculiar problems they pose will "frustrate the purposes of the formation of the Union" only when the disadvantage affects a fundamental activity reflects either an unduly limited view of what those purposes are, or an empirically dubious assumption about human nature. In Baldwin, Justice Blackmun described the category of fundamental activities sufficient to trigger the protection of the privileges and immunities clause as those "basic to the maintenance or well-being of the Union" or "basic to the livelihood of the Nation." meant to say that only those activities crucial to the economic prosperity of the nation qualify, his view cannot be supported. The comity clauses were designed to promote political and social cohesion among the people of the several states, as well as to establish a favorable framework for economic growth. The Framers sought to ensure a unifying hospitality, as well as commercial productivity, when they acted, in the words of the Articles of Confederation, "to secure and perpetuate mutual friendship and intercourse among the people of the different States in this Union." have meant that, unless an activity is fundamental, unnecessary discriminations against nonresidents do not realistically threaten the social, economic, or political unification of the nation. If so, his conclusion seems at odds with the way people normally react to unjustifiable denials or limitations of access to opportunities readily available to insiders. It is easy to imagine a nonresident feeling greater hostility towards a state that excludes him totally from, or charges him vastly more for, a recreational activity available to residents than towards a state that charges a little more for a commercial fishing license than can be justified by the fact of nonresidence. Yet under Baldwin, the former discrimination is immune from the limitations of the clause while the latter is subject to them. If California entirely excluded nonresidents from its state

- See id. at 388-91.

97 Id. at 388.

- ARTicles of Confederation art. IV; see note 2 supra. Even if one believes the comity clauses were intended solely to create a common market, social consequences are important. The more hostility a nonresident perceives directed at him, the less likely he is to trade in the state. 
beaches, would the Court really find the exclusion permissible? Limiting the cost of maintaining the beaches would surely make the distinction rational for purposes of equal protection, and under Baldwin the privileges and immunities clause seemingly would not apply because the nonresident sought access to a nonfundamental recreational activity. But it is hard to square such a result with the interstate unification aims of the Constitution.

A second objection to the use of the fundamentality criterion is the vexing problem of definition. The Court declined to explain in Baldwin what generally distinguishes fundamental or basic privileges and immunities. Instead, it simply decided that whatever the dividing line, recreational elk hunting was certainly on the nonfundamental side.99 Justice Blackmun did suggest, however, that he had in mind the "modern . . . sense" of fundamentality applied by Justice Washington ${ }^{100}$ in the seminal case of Corfield $v$. Coryell. ${ }^{101}$

But just what is the "modern sense" Justice Blackmun had in

936 U.S. at 388.

${ }^{100}$ Id. at 387. Justice Blackmun qualified his reliance on Justice Washington, however, and made it clear that he was not invoking the concept of natural rights, on which Justice Washington "seemingly relied" in part. Id.

${ }^{101} 6$ Fed. Cas. 546 (C.C.E.D. Pa. 1823) (No. 3230). Justice Washington's classic passage reads:

The inquiry is, what are the privileges and immunities of citizens in the several States? We feel no hesitation in confining these expressions to those privileges and immunities which are, in their nature, fundamental; which belong, of right, to the citizens of all free governments; and which have, at all times, been enjoyed by the citizens of the several states which compose this Union, from the time of their becoming free, independent, and sovereign. What these fundamental privileges are, it would perhaps be more tedious than difficult to enumerate. They may, however, be all comprehended under the following general heads: Protection by the government; the enjoyment of life and liberty, with the right to acquire and possess property of every kind, and to pursue and obtain happiness and safety; subject nevertheless to such restraints as the government may justly prescribe for the general good of the whole. The right of a citizen of one state to pass through, or to reside in any other state for purposes of trade, agriculture, professional pursuits, or otherwise; to claim the benefit of the writ of habeas corpus; to institute and maintain actions of any kind in the courts of the state; to take, hold and dispose of property, either real or personal; and an exemption from higher taxes or impositions than are paid by the other citizens of the state; may be mentioned as some of the particular privileges and immunities of citizens, which are clearly embraced by the general description of privileges deemed to be fundamental; to which may be added, the elective franchise, as regulated and established by the laws or constitution of the state in which it is to be exercised.

$I d$. at 551-52. Professor Ely suggests that "Washington purported to place limits but ended up with a virtually infinite reference . . . J. J. ELY, Democracy AND DisTrusT 28 (1980). Even if Washington's understanding of what was fundamental "wasn't much of a limitation," id. at 29, however, Baldwin creates an urgent need for some definition. 
mind? It is important to understand that it cannot be the same sense in which the term is used in modern equal protection analysis. Under the equal protection clause, the Court normally upholds the constitutionality of a state classification if it is at all rational to single out the disadvantaged group for treatment different from that afforded the advantaged group. ${ }^{102}$ But if the classification impinges upon a "fundamental interest," the Court will uphold the classification only if the state can demonstrate that the classification is necessary to serve a compelling state interest. ${ }^{103}$ The category of fundamental interests in equal protection doctrine is quite limited, ${ }^{104}$ and the Burger Court has rejected any attempts to expand its scope. ${ }^{108}$ If it took a fundamental equal protection interest to activate the protection of the privileges and immunities clause, the clause would be rendered superfluous. As Baldwin itself indicates, nonresidents as a class are protected by the equal protection clause when they are within another state's jurisdiction, and given the presence of a fundamental equal protection interest, strict scrutiny would apply without any help from the comity clauses. ${ }^{108}$ Moreover, the Court has never indicated any intention to define the category of fundamental privileges and immunities this narrowly. For example, the right to pursue a particular livelihood, which the Court never hesitates to find protected under the privileges and immunities clause, ${ }^{107}$ is not a fundamental interest under the equal protection clause. ${ }^{108}$ Furthermore, whenever the privi-

${ }^{102}$ See L. TRIBE, supra note 46, $\S 16-2$ to -4 . See generally Gunther, The Supreme Court, 1971 Term-Foreword: In Search of Evolving Doctrine on a Changing Court: A Model for a Newer Equal Protection, 86 Harv. L. Rgv. 1 (1972); Developments in the Law-Equal Protection, 82 HARv. L. REv. 1065, 1076-87 (1969) [hereinafter cited as Developments].

${ }^{103}$ See Shapiro v. Thompson, 394 U.S. 618, 634, 638 (1969); L. TRIBE, supra note 46, \$§ 16-7 to -12; Developments, supra note 102, at 1120-23, 1127-31.

${ }^{104}$ As Professor Gunther pointed out: "The list of interests identified as fundamental by the Warren Court was in fact quite modest: voting, criminal appeals, and the right of interstate travel were the prime examples." Gunther, supra note 102, at 8-9.

${ }^{105}$ E.g., San Antonio Independent School Dist. v. Rodriguez, 411 U.S. 1 (1973); see Gunther, supra note 102, at 12-15.

106 Voting is an exception. Although the right to vote is a fundamental equal protection interest with respect to classifications among state residents, see, e.g., Kramer v. Union Free School Dist., 395 U.S. 621, 626-28 (1969), nonresidents have no constitutional claim to participate in another state's political process. See text at notes 142-147 infra.

${ }^{107}$ E.g., Hicklin v. Orbeck, 437 U.S. 518 (1978); Mullaney v. Anderson, 342 U.S. 415 (1952); Toomer v. Witsell, 334 U.S. 385 (1948); Ward v. Maryland, 79 U.S. (12 Wall.) 418 (1871).

${ }^{108}$ See, e.g., City of New Orleans v. Dukes, 427 U.S. 297 (1976); McGowan v. Maryland, 366 U.S. 420 (1961); Williamșon v. Lee Optical Co., 348 U.S. 483 (1955); Kotch v. Board of 
leges and immunities clause applies under the fundamentality doctrine, the Toomer standard of review presumably governs the validity of any residence classification. That standard, although considerably stricter than minimum rationality, is not as rigid as that applicable to classifications impinging on equal protection fundamental interests. ${ }^{109}$ Fundamentality could not mean the same thing in both contexts, therefore, unless nonresidents as a class were to be given less judicial protection than similarly situated residents. This would be a curious result, considering that the Constitution originally singled out nonresidents for special protection by the privileges and immunities clause and that they now have the additional safeguard of the equal protection clause. ${ }^{110}$

In fact, it is the branch of equal protection doctrine that varies the level of scrutiny according to the nature of the trait used to classify, ${ }^{111}$ rather than the fundamentality of the interest affected by the classification, that most closely parallels the concerns under the privileges and immunities clause. Independently of the interest affected, the Court examines government classifications more closely when the disadvantaged group is identified by traits such as race, ${ }^{112}$ gender, ${ }^{113}$ alienage,${ }^{114}$ or illegitimacy ${ }^{115}$ than when the basis of classification creates less risk that a group was disadvantaged because it was the object of prejudice or insensitivity. The privi-

River Port Pilot Comm'rs, 330 U.S. 552 (1947).

${ }^{109}$ Toomer requires a "substantial," but not a "compelling," reason for the discrimination, and a "close," but not a "necessary," relationship between the degree of discrimination and the valid reasons for it. Toomer v. Witsell, 334 U.S. 385, 396 (1948), quoted in note 94 supra. As others have noted, see I. TriBE, supra note 46, § 6-33, at 411 n.17; Note, Hughes v. Oklahoma and Baldwin v. Fish and Game Commission: The Commerce Clause and State Control of Natural Resources, 66 VA. L. Rev. 1145, 1146 n.9 (1980), the Toomer standard closely resembles the "intermediate" level of scrutiny the Court applies in cases of gender discrimination, namely, whether the gender classification serves "important governmental objectives" and is "substantially related to the achievement of those objectives," Craig v. Boren, 429 U.S. 190, 197 (1976).

110 But see note 106 supra.

11 See generally L. TRIBE, supra note 46, §§ 16-13 to -29 .

112 See, e.g., Loving v. Virginia, 388 U.S. 1, 11-12 (1967). See also Lee v. Washington, 390 U.S. 333 (1968) (per curiam); Holmes v. City of Atlanta, 350 U.S. 879 (1955) (per curiam).

${ }_{113}$ See, e.g., Wengler v. Druggists Mutual Ins. Co., 446 U.S. 142, 150-52 (1980); Califano v. Goldfarb, 430 U.S. 199, 210-12 (1977); Frontiero v. Richardson, 411 U.S. 677, 682-88 (1973).

"14 See, e.g., Sugarman v. Dougall, 413 U.S. 634, $641-46$ (1973); Graham v. Richardson, 403 U.S. $365,371-72$ (1971).

${ }^{115}$ See, e.g., Trimble v. Gordon, 430 U.S. 762 (1977); Weber v. Aetna Cas. \& Sur. Co., 406 U.S. 164, 172-76 (1972). 
leges and immunities clause similarly provides special protection for nonresidents as a class because they might otherwise be systematically disadvantaged. Moreover, nonresidents possess two characteristics that generally call for at least some special judicial solicitude under the equal protection clause, whether or not fundamental activities are affected: they lack the right to vote, and they are vulnerable to local prejudice or insensitivity. ${ }^{116} \mathrm{It}$ is undoubtedly because of the "quasi-suspect" nature of the residence classification that the Court applies an elevated standard of review when the clause is triggered. But that only makes it harder to understand why the Court's approach to residence classifications should differ from its general approach to other classifications eliciting special scrutiny. Nonresidents, despite the added protection of the privileges and immunities clause, are the only "quasi-suspect" group for which there is no.special review unless there is also a "fundamental" activity affected. The result is inexplicably to denigrate the constitutional concern with the use of state residence as a basis for classification and to shift the focus to the fundamentality of the activity in dispute.

Furthermore, even if it is clear that fundamentality must be defined differently for the privileges and immunities clause than for the equal protection clause, it still is unclear what the touchstone of definition is to be. Under equal protection doctrine, the Court has eschewed the process of comparing the "relative societal significance" of different activities or benefits as a way of measuring fundamentality, ${ }^{117}$ and it has confined the concept of fundamental interests to those rights "explicitly or implicitly guaranteed by the Constitution."118 It is unclear why the Court should be more willing to undertake to rank activities on a scale of social importance in order to determine which are fundamental enough to trigger the application of the privileges and immunities clause. The process may differ somewhat from that necessary in the equal protection context, but it is just as difficult.

In short, the fundamentality doctrine reaffirmed in Baldwin

11e In San Antonio Independent School Dist. v. Rodriguez, 411 U.S. 1, 28 (1973), Justice Powell summarized "the traditional indicia of suspectness" as belonging to "the class . . . saddled with such disabilities, or subjected to such a history of purposeful unequal treatment, or relegated to such a position of political powerlessness as to command extraordinary protection from the majoritarian political process." For a relevant comparison of the status of aliens who reside in a state and nonresidents, see text at notes 152-163 infra.

117 San Antonio Independent School Dist. v. Rodriguez, 411 U.S. 1, 33 (1973).

${ }^{118}$ Id. at 33-34. 
reflects neither an appreciation of the instances in which interstate divisiveness is likely to result from residence classifications, nor the fundamental interest or suspect classification approaches to equal protection, nor any other discernible concept that can be tied to the purposes of the privileges and immunities clause. It is, instead, an historical relic lacking independent content. Furthermore, it deflects attention from the real differences between a state's relationship to its own residents and its relationship to the residents of other states, differences that might justify deviation from a strict rule of equal treatment.

\section{Accommodating the Claims of State "Citizenship" and INTERSTATE EQUALITY}

The Framers of the Constitution were compromisers. The demonstrated defects of the Articles of Confederation led them to seek a stronger national government, ${ }^{119}$ but state loyalties and fear of centralized authority compelled the retention of the states as separate political communities. ${ }^{120}$ As a result, the Framers chose-or settled for-a Constitution that is, in the words of Madison, "in strictness, neither a national nor a federal Constitution, but a composition of both."121 That compromise on the fundamental governmental structure of the union has provided a breeding ground for conflicts between state and national authority ever since. In the context of state discrimination on the basis of residence, there is an inherent conflict between the objectives of the Constitution's interstate equality provisions and the continued significance of state government.

At first glance, the Constitution appears to eliminate any room for conflict by providing an ironclad rule against state residence discrimination. The unqualified language of the privileges and immunities clause ${ }^{122}$ suggests that the architects who designed a federal structure composed of constituent states with full government powers generally diminished only by the powers delegated to the national government also deliberately included in their original set of plans a comprehensive ban on state discrimination against the citizens of other states. Moreover, the national free-trade objec-

119 See The Federalist Nos. 1, 15, 21, 22, 30, 85 (Hamilton), 38, 41, 42 (Madison).

120 See The Federalist Nos. 17, 31, 32, 34 (Hamilton), 45, 46 (Madison).

121 The Federalist No. 39 (Madison), at 246 (C. Rossiter ed. 1961) [all subsequent page references to The Federalist are to the Rossiter edition].

122 Quoted in text at note 6 supra. 
tives of the commerce clause seem incompatible with any state authority to treat in-state business more favorably than out-ofstate business.

Yet the continuation of state government as contemplated by the Framers necessarily requires recognition of some state authority to treat residents more favorably than nonresidents ${ }^{123}$ and some power to deviate from a completely open economy. ${ }^{124}$ In the elkhunting case, Justice Blackmun said that "[s]ome distinctions between residents and nonresidents merely reflect the fact that this is a Nation composed of individual States, and are permitted; other distinctions are prohibited because they hinder the formation, the purpose or the development of a single Union of those States."125 The statement is helpful only insofar as it suggests that our federal structure contemplates the validity of some residence distinctions. It does not help clarify which distinctions legitimately reflect the separate existence of the states. Nor does it seem to recognize the real possibility that some residence distinctions may simultaneously reflect our federal structure and hinder the objectives of union, so that evaluation of their validity requires a choice between competing values. A theory that would separate permissible from impermissible residence distinctions should take account of the aims of the constitutional interstate equality provisions that, if not absolutely, at least presumptively bar state discrimination against nonresidents; isolate the attributes of state government that prima facie will justify state resident preference; and articulate any special factors tending to rebut the prima facie case and shift the balance back in favor of interstate equality.

\section{A. The Constitutional Rationale for Interstate Equality}

One modern explanation of the interstate equality provisions focuses on the fact that residents of one state have no voter control over the representatives of other states. It suggests that the Framers, sensitive to this absence of political accountability, substituted constitutional equality principles to protect the interests of the unrepresented nonresident. ${ }^{126}$ As Professor Ely puts it, the constitu-

${ }^{123}$ See the passage from Toomer $v$. Witsell set forth in note 94 supra for the Court's recognition that "[l]ike many other constitutional provisions, the privileges and immunities clause is not an absolute." 334 U.S. at 396.

124 See text at notes 147-149 infra.

125 Baldwin v. Fish \& Game Comm'n, 436 U.S. 371, 383 (1978).

${ }_{196}$ See, e.g., Simson, Discrimination Against Nonresidents and the Privileges and Im- 
tional protection of nonresidents "proceeds by what amounts to a system of virtual representation: by constitutionally tying the fate of outsiders to the fate of those possessing political power, the framers insured that their interests would be well looked after."127 This analysis may demonstrate how the equality objective was to be achieved, but it does not tell us why it was thought important that nonresidents as a class should be "well looked after." This is especially puzzling because certain classes of disenfranchised residents lacked any similar constitutional protection. ${ }^{\mathbf{1 2 8}}$

The reason is clear. The Framers adopted the constitutional ban on state discrimination against nonresidents and interstate relationships primarily as an instrument of national unification. Hamilton deemed the privileges and immunities clause "the basis of the union."129 The antidiscrimination principle of the commerce clause similarly was designed to forestall divisions along state lines. ${ }^{130}$ However divided on the specifics of application, the Court has never doubted the centrality of this guiding purpose.

At a fundamental level, then, the goals of these clauses are no less comprehensive than the objects of union. Decreasing the significance of state residence tends to strengthen interstate attachments and thereby diminish the likelihood of interstate conflicts. ${ }^{131}$ At the same time, external threats to the country's security are more likely to be deterred if the nation is cohesive and not split along state lines. ${ }^{132}$ Economically, the establishment of a federal free-trade unit was designed not only to contribute to the nation's political solidarity, but also to produce material prosperity and to maximize individual opportunity. ${ }^{13 s}$ The same reasons explain why

munities Clause of Article IV, 128 U. PA. L. REv. 379, $384-85$ (1979).

127 J. ELY, supra note 101, at 83.

${ }^{128}$ Professor Simson suggests that although the Framers were moved by a general commitment to representative government, they thought disenfranchised residents, unlike nonresidents, would receive political protection "by virtue of kinship [with] or other ties" to enfranchised residents. Simson, supra note 126, at 384-85. Whatever may be said of women or children, however, it seems historically doubtful that nonwhites or aliens had, or were perceived to have had, better surrogate political representation in state legislative halls than did the citizens of other states.

128 The Federalist No. 80 (Hamilton), at 478.

${ }^{130}$ See H.P. Hood \& Sons, Inc. v. Du Mond, 336 U.S. 525, 533-35 (1949).

131 See The Frderalist Nos. 6-9, 11 (Hamilton).

132 See The Federalist Nos. 3-5 (Jay).

13s The material success that has come to inhabitants of the states which make up this federal free trade unit has been the most impressive in the history of commerce, but the established interdependence of the states only emphasizes the necessity of protecting interstate movement of goods against local burdens and repressions. . . . 
the privileges and immunities clause prescribed that wherever a member of the nation traveled he would be treated the same as local residents. ${ }^{134}$ By restricting state power to limit or discourage either creation of advantageous interstate relationships or the nonresident's pursuit of advantages found in other states, the nondiscrimination principles foster cumulative attachments among people in different states, maximize individual opportunities for selfbetterment, and increase aggregate productivity. At the same time, they leave people free to make their home in one state without sacrificing the opportunity to share in the bounty found in others. True, the states are constitutionally forbidden to exclude individuals who wish to take up permanent residence within their borders, ${ }^{135}$ and this right of interstate migration limits state authority to treat bona fide, albeit recently arrived, residents less well than longer-term residents. ${ }^{138}$ But the Constitution goes even further: the interstate equality guarantees protect nonresidents who do not wish to relocate their homes, but do wish to travel to or through, or trade with, other states in order to take advantage of opportunities available in other parts of the country. In this way, the range of choices open to members of the union is enhanced.

\section{B. State Government and State "Citizenship"}

The objective of national unification certainly could be achieved just as well, if not better, by a unitary national govern-

Our system, fostered by the Commerce Clause, is that every farmer and every craftsman shall be encouraged to produce by the certainty that he will have free access to every market in the Nation, that no home embargoes will withhold his exports, and no foreign state will by customs duties or regulations exclude them. Likewise, every consumer may look to the free competition from every producing area in the Nation to protect him from exploitation by any. Such was the vision of the Founders; such has been the doctrine of this Court which has given it reality.

H.P. Hood \& Sons, Inc. v. DuMond, 336 U.S. 525, 538-39 (1949).

124 See Ward v. Maryland, 79 U.S. (12 Wall.) 418, 430-32 (1871); cases cited note 107 supra.

13s Dunn v. Blumstein, 405 U.S. 330, 338 (1972); Edwards v. California, 314 U.S. 160 (1941).

130 Thus the Court has invalidated, as "penalties" for exercising the right of interstate travel, state durational residency requirements as a condition of eligibility to receive nonemergency hospitalization or medical care, Memorial Hosp. v. Maricopa County, 415 U.S. 250 (1974), to vote, Dunn v. Blumstein, 405 U.S. 330 (1972), and to receive welfare assistance, Shapiro v. Thompson, 394 U.S. 618 (1969). In each of these cases, the residence requirement was not supported by any compelling interest. Shapiro expressly reserved the question of whether all such requirements were penalties. Id. at $638 \mathrm{n} .21$. See Sosna v. Iowa, 419 U.S. 393 (1975), upholding a one-year durational residency requirement before a new resident could use the state courts to sue a nonresident for divorce. 
ment structure as by the composite of national and federal government created by the Constitution. But the Framers did retain state government, and in doing so they made some basic assumptions about the nature of state communities and the scope of state powers and functions. These assumptions compel recognition of some state power to deviate from the apparently flat prohibition against state discrimination on the basis of residence.

Fundamentally, the states are, and were intended to be, quasisovereign political communities, rather than conveniently local administrative departments of the national government designed to assist in the implementation of national policy. ${ }^{137}$ They are republican (that is, representative) governments, accountable to local constituencies. ${ }^{138}$ They possess a large measure of lawmaking authority, independent of the lawmaking power of other states and the federal government, to govern the people and events within their fixed territorial boundaries. ${ }^{138}$ The purpose of that lawmaking power is to provide public benefits and services within the territories they govern. The states' ability to experiment in a local setting is a frequently cited advantage of our federal structure, ${ }^{140}$ and in light of the freedom of interstate migration, ${ }^{141}$ the resulting pattern of different packages of collective goods in each state provides the nation's residents with a wide range of alternatives from which to choose.

These basic features of state government necessarily imply some valid distinctions between residents and nonresidents. Consider the question of eligibility to vote in state elections. If the states are to be representative governments exercising their powers within the state's boundaries, their constituencies must surely be defined by the line between those who make their home in the state and those who do not. The very existence of a constitutional

197 See The Federalist No. 45 (Madison), at 292-93.

138 U.S. CoNST. art. IV, § 4, provides that "[t]he United States shall guarantee to every State in this Union a Republican Form of Government. . . " See The Federauist No. 43 (Madison), at 274-78.

139 See The Frderalist No. 45 (Madison), at 292-93. The structural foundation of the federal system is expressed in the tenth amendment, which provides: "The powers not delegated to the United States by the Constitution, nor prohibited by it to the States, are reserved to the States respectively, or to the people."

140 E.g., New State Ice Co. v. Liebmann, 285 U.S. 262, 311 (1932) (Brandeis, J., dissenting): "It is one of the happy incidents of the federal system that a single courageous State may, if its citizens choose, serve as a laboratory; and try novel social and economic experiments without risk to the rest of the country."

${ }^{141}$ See cases cited note 135 supra. 
guarantee of equality of treatment when a citizen of one state travels to another presupposes the absence of voting power. A system of "virtual representation" would be unnecessary if a state could not deny nonresidents the right to vote in its elections. The basic assumptions must be that no person has a right to vote in more than one state's elections, that the state of one's residence is the appropriate state in which to vote, and that in all the other states the nonresident is to be protected by constitutional guarantees against discrimination on the basis of residence.

Denying the vote to nonresidents is, of course, not the same as denying the vote to those who recently became residents. Because the right to vote is a fundamental political interest, the Supreme Court has applied strict scrutiny to selective distribution of the franchise among different classes of residents ${ }^{142}$ and has struck down lengthy durational residency requirements disenfranchising bona fide, but recently arrived, residents. ${ }^{143}$ At the same time, however, the Court has reaffirmed state "power to require that voters be bona fide residents of the relevant political subdivision."144 Fundamental as the right to vote is, "[a]n appropriately defined and uniformly applied requirement of bona fide residence may be necessary to preserve the basic conception of a political community, and therefore could withstand close constitutional scrutiny." "145 The new resident is no longer entitled to vote in the state he left, ${ }^{146}$ and the nonresident may be denied the right to vote in the states that he merely visits. Though a state may not interfere with an individual's choice to take up residence within its borders, and is limited in the criteria it may use to ensure that the individual is a bona fide resident, it may require the individual to make a choice. He is entitled to the status of voting member in only one state political community at a time. ${ }^{147}$

Just as the basic conception of states as discrete political com-

142 See Dunn v. Blumstein, 405 U.S. 330 (1972); Kramer v. Union Free School Dist., 395 U.S. 621 (1969); Harper v. Virginia Bd. of Elections, 383 U.S. 663 (1966).

${ }^{14 s}$ See Dunn v. Blumstein, 405 U.S. 330 (1972). But see Marston v. Lewis, 410 U.S. 679,680 (1973) (per curiam) (approving 50-day durational residency requirements "to prepare adequate voter records and protect [the state's] electoral processes from possible frauds").

14 Dunn v. Blumstein, 405 U.S. 330, 343 (1972).

14 Id. at 343-44; see L. TRIBE, supra note 46, § $13-12$.

${ }_{146}$ Cf. Califano v. Torres, 435 U.S. 1, 4 (1978) (per curiam) (dictum) (constitutional right to travel does not require a state to continue to pay welfare bénefits to former residents after they move out of the state).

147 Accord, Beale, Residence and Domicil, 4 Iowa L. Bull. 3, 5 (1918). 
munities implicitly justifies restricting the right to vote in state elections to residents, so, too, the Constitution's fundamental assumptions about state powers and functions implicitly suggest the legitimacy of additional residence distinctions. The states' wide range of independent lawmaking authority necessarily prevents complete realization of a national free-trade unit. When the Framers provided for concurrent federal and state taxing, spending, and regulatory powers, they sanctioned a diversity of policies among the states. That diversity inevitably distorts business location and resource allocation decisions from what they would be in a true free-trade area. The Framers thus compromised to some degree the national free-trade objectives of the commerce clause in the interest of state power. If sufficiently important to the fulfillment of core state functions, certain distinctions based on residence might also be justified despite their incompatibility with strict adherence to the unification objective of the commerce and privileges and immunities clauses.

Those provisions clearly were intended to outlaw state discrimination on the basis of residence in the regulation of access to the private sector. ${ }^{148} \mathrm{On}$ the other hand, the states certainly were expected to establish public sector programs and services, and it was much less clear that residence could not be made a necessary qualification of participation in those. Hamilton conceded the "justness of the reasoning which requires that the individual States could possess an independent and uncontrollable authority to raise their own revenues for the supply of their own wants."148 If that "independent and uncontrollable authority" is to have real substance, it may sometimes be necessary to recognize state power to limit publicly funded programs to residents. At a minimum, such power should be recognized whenever requirements of equal sharing with nonresidents probably would result in no program being created for anyone. For example, no state would be inclined to adopt welfare programs if it could not do so without providing benefits to poor nonresidents who simply traveled to the state periodically to collect welfare benefits. The "free-rider" problem presented by all those who remain residents of one state, but might visit another for the purpose of sharing in its public resources if their temporary presence would establish their eligibility, would surely eliminate the states' incentive to adopt assistance

148 See text and notes at notes 14-18 supra.

169 The Federalist No. 32 (Hamilton), at 197-98. 
programs. ${ }^{180}$

The states' independent lawmaking authority suggests an even broader range of state power to limit public sector resources to residents. Arguably, at least in the absence of special circumstances, only the members of a group providing a service have a legitimate claim of entitlement to it. Like other groups free to combine their members' efforts to produce collective benefits to be shared among the group, political communities, including states, have a prima facie justification for limiting distribution of their public goods to those who combined to provide them.

Before using this "Lockean labor-desert theory"161 as a presumptive justification for allocating state-created benefits to state residents first, however, it is necessary to establish that the line between residents and nonresidents in fact separates those who contribute jointly to the creation of benefits from those who do not. Establishment of state programs requires both state resources and decisions about how to use them. It is sensible, therefore, to examine both the class of people contributing to the state's coffers and the class entitled to participate in the formulation of state policy to see whether the residence distinction is valid.

The state's electorate has the authority to participate, usually through state representatives, in deciding which public goods will be provided and in what quantities. But that nonresidents may be denied the right to vote cannot be used to justify denying them a right to share in most public services. Some residents also may be denied the right to vote, but they generally may not be denied a right to share in public programs on the same terms as their enfranchised coresidents.

An historical comparison of the status of nonresidents and aliens residing in a state ${ }^{162}$ is instructive in this regard. Neither of these groups has ever been thought to have a constitutional right

180 I think this is a better explanation for the validity of bona fide residency requirements as a condition to welfare than an explanation that rests on the admittedly "inexact" "premise that indigent residents ultimately compensate the state's taxpayers much more adequately than do indigent nonresidents," or an explanation asserting that the "classification . . . is as precise as the state's rather open-ended goal permits." Simson, supra note 126, at 398 .

${ }^{251}$ See Michelman, Property, Utility, and Fairness: Comments on the Ethical Foundations of "Just Compensation" Law, 80 HARv. L. REv. 1165, 1204-05 (1967).

158 I shall use the terms "aliens residing in the state" or "in-state aliens," rather than "resident aliens." The latter term frequently is used to contrast aliens living outside the United States with aliens residing anywhere within the nation's boundaries. The focus here is on aliens residing in the state whose law is at issue. 
to vote, nor to participate in state policy formulation, on a par with state citizens. ${ }^{153}$ At one time, however, our constitutional law permitted more state discrimination against in-state aliens than against nonresident citizens. The Supreme Court even said, when discussing the equality principle of the privileges and immunities clause, that the clause was designed to remove "the disabilities of alienage" from state citizens when they were within states not their own. ${ }^{154}$ Well into the twentieth century, the states were permitted to deny in-state aliens the right to earn a livelihood in occupations they could not bar nonresident citizens from pursuing. ${ }^{155}$ But the Court eventually turned the situation completely around and began to interpret the equal protection clause of the fourteenth amendment to limit state power to discriminate against instate aliens more severely than it has ever limited state power to discriminate against out-of-state citizens. ${ }^{156}$

Today, aliens residing in a state are constitutionally entitled to share in welfare benefits on an equal basis with other residents, ${ }^{157}$ though most agree that the inhabitants of other states are not. ${ }^{168}$ Similarly, although the states were at one time permit-

16s With respect to nonresidents, see Dunn v. Blumstein, 405 U.S. 330, 343-44 (1972). With respect to in-state aliens, see Ambach v. Norwick, 441 U.S. 68, 73-74 (1979) ("some state functions are so bound up with the operation of the State as a governmental entity as to permit the exclusion from those functions of all persons [including aliens] who have not become part of the process of self-government"); Sugarman v. Dougall, 413 U.S. 634, 647 (1973) (declaring that a state's "power and responsibility" to preserve the basic conception of a political community by imposing citizenship requirements "applies, not only to the qualifications of voters, but also to persons holding state elective or important nonelective executive, legislative, and judicial positions, for officers who participate directly in the formulation, execution, or review of broad public policy perform functions that go to the heart of representative government").

154 Paul v. Virginia, 75 U.S. (8 Wall.) 168, 180 (1869).

${ }^{185}$ Although the Court protected the right of aliens to earn a livelihood in the ordinary private sector occupations of the community, Truax v. Raich, 239 U.S. 33, 41-42 (1915), it permitted the states to exclude certain aliens (largely those ineligible for naturalization) from owning, leasing, or otherwise controlling private property devoted to farming, Frick v. Webb, 263 U.S. 326 (1923); Webb v. O'Brien, 263 U.S. 313 (1923); Terrace v. Thompson, 263 U.S. 197, 216-22 (1923), something the state presumably could not have done to citizens residing in other states. See cases cited note 17 supra. See also Clarke v. Deckebach, 274 U.S. 392 (1927) (upholding a state law forbiding aliens from operating billiard parlors).

${ }^{186}$ The first major breakthrough came in 1948, when the Court invalidated a California law "barring issuance of commercial fishing licenses to persons ineligible for citizenship under federal law," Takahashi v. Fish \& Game Comm'n, 334 U.S. 410, 414 (1948), and held that the states could not "prevent lawfully admitted aliens within its borders from earning a living in the same way that other state inhabitants earn their living," id. at 418-19.

${ }_{187}$ Graham v. Richardson, 403 U.S. 365 (1971).

${ }^{18 s}$ See, e.g., Simson, supra note 126, at 397-98. 
ted to exclude their alien inhabitants from public employment, ${ }^{159}$ an in-state alien now has a right to the same consideration citizens of that state receive for at least those state jobs that do not involve the political operation of the state. ${ }^{160}$ But it is not thought to follow automatically from the in-state alien's entitlement to consideration for public employment that a resident of another state is similarly entitled. ${ }^{101}$ Whether a state may constitutionally confine public sector employment to residents, or even give residents preference over nonresidents, remains undecided. ${ }^{162}$

159 Heim v. McCall, 239 U.S. 175 (1915); Crane v. New York, 239 U.S. 195 (1915).

${ }^{160}$ Sugarman v. Dougall, 413 U.S. 634, 641-46 (1973) (invalidating a law rendering aliens ineligible for permanent positions in the state's civil service). But see Ambach v. Norwick, 441 U.S. 68, 75 (1979) (upholding a state ban on certification as a public school teacher of any alien who has not manifested an intention to apply for citizenship, because public school teachers come within the "rule for governmental functions, which is an exception to the general standard applicable to classifications based on alienage"); Foley v. Connelie, 435 U.S. 291 (1978) (upholding exclusion of aliens from state police jobs).

${ }_{161}$ See Simson, supra note 126 , at 392 n.63.

162 The fact that constitutional doctrine now seems to provide greater protection for instate aliens than for out-of-state citizens requires rethinking of whether a state may single out aliens who reside in other states for unfavorable treatment within its own jurisdiction. The conventional understanding is that aliens are not included among "[t]he Citizens of each State" who "are entitled to all Privileges and Immunities of Citizens in the several States," U.S. Const. art. IV, § 2, cl. 1. See D. Fehrenbacher, Thz Dred ScotT Case 359

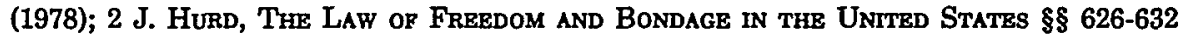
(Boston 1862); J. NowaK, R. Rotunda \& J. Young, supra note 46, at 380; L. Tribe, supra note 46, § 6.33, at 411 n.18. See also Simson, supra note 126, at 380 n.10, citing Hicklin v. Orbeck, 437 U.S. $418,531 \mathrm{n.15}$ (1978), as indicative of this view. In fact, the Court's point there is quite different. Discounting the relevance to a privileges and immunities claim of two cases, Heim v. McCall, 239 U.S. 175 (1915), and Crane v. New York, 239 U.S. 195 (1915), which rejected constitutional objections to a statute reserving public works jobs for United States citizens and requiring preference to be given to the state's citizens, the Court noted that, even if those cases "have any remaining vitality," "no out-of-state United States citizen [had] challenged the law." As a result, those cases "were concerned almost exclusively with the statute's discrimination against resident aliens" (i.e., aliens residing in the state). Therefore, Heim and Crane "expressed no view on [the plaintiffs'] passing Art. IV, $\S 2$, privileges and immunities claim." No out-of-state alien had challenged the law either, and the footnote reference in Hicklin therefore does not endorse the exclusion of aliens from the protection of that clause.

The Court has never had to decide the issue of state power to discriminate against outof-state aliens, but it has assumed in dicta, both before and after the adoption of the fourteenth amendment in 1868 , that aliens are not protected by the interstate privileges and immunities clause. E.g., Blake v. McClung, 172 U.S. 239, 247 (1898); Paul v. Virginia, 75 U.S. (8 Wall.) 168, 177 (1869); Scott v. Sandford, 60 U.S. (19 How.) 393, 419 (1857). That assumption undoubtedly is based on the further assumption that the term "citizen," however broadly construed, does not include persons who owe their allegiance to a foreign state. E.g., Baldwin v. Franks, 120 U.S. 678, 690 (1887); Minor v. Happersett, 88 U.S. (21 Wall.) 162,166 (1875) (construing the word "citizen" as used in the Constitution broadly to mean the "membership of a nation, and nothing more," but defining membership to require political "allegiance" to the nation). See generally J. Wise, A Treatise on AMERIcan Citizenshir 


\section{A comparison of the entitlements of in-state aliens and out-of-}

3-5 (1906). It is possible, of course, to construe "citizen" more expansively, as meaning "resident, inhabitant, or person." Baldwin v. Franks, 120 U.S. 678, 690 (1887). The word "inhabitant" was used in article IV of the Articles of Confederation, quoted in note 2 supra, and Madison thought it a "construction scarcely avoidable" that aliens residing in other states were thereby protected, The Federalist No. 42 (Madison), at 270. Although the Constitution's fourth article substituted the word "citizen" for the word "inhabitant," Charles Pinckney, who claimed authorship of the article, see sources cited in Simson, supra note 126, at 383 n.23 (but see W. WiEceK, The Sources of ANTislavery Constitutionalism in AMERICA, 1760-1848, at 123, 164 (1977) (asserting that Pinckney was not the draftsman)), told the Constitutional Convention that the fourth article of his plan was "formed exactly upon the principles of the 4th article of the present Confederation," except in the provision governing the delivery of fugitives from justice. 3 THE Records OF THE FEDERAL CoNveNTION OF 1787, at 112 (M. Farrand ed. 1911). An argument might be made, therefore, that no change excluding aliens from the protection of the comity clause was intended by the use of the word "citizen."

But the argument fails, not because of Chief Justice Taney's assumption (neither supported nor refuted by historical evidence) that "this alteration in words would hardly have been made, unless a different meaning was intended to be conveyed, or a possible doubt removed," Scott v. Sandford, 60 U.S. (19 How.) 393, 419 (1857), but because the meaning of "citizenship" for purposes of article IV, section 2 was linked historically with the article I grant to Congress of the power "[t]o establish a uniform Rule of Naturalization," U.S. CoNST. art. I, § 8, cl. 4. Madison's argument in favor of delegating the power to naturalize to Congress rested on the concern that, even if the guarantees of interstate equality were limited to persons granted citizenship status by their state of residence, one state might admit to citizenship, and thereby provide protection in a second state for, persons who would not have qualified for citizenship in the second state had they resided there. The FEDRRausT No. 42 (Madison), at 270.

This concern indicates that Madison assumed the privileges and immunities clause did not protect aliens, and that national rather than state citizenship was the touchstone of coverage. The language of the clause appears to make state citizenship the touchstone, however, and, until the Dred Scott case, debate raged on the issues of whether free blacks were citizens for purposes of article IV and whether it was state or national citizenship that counted. D. Fenrensacher, supra, at 64-73; W. WIECEK, supra, at 123, 139-41, 162-67. The Court held that national citizenship was required to invoke the privileges and immunities clause. In concluding that the Framers' bestowal of the power of naturalization on Congress at the same time they adopted the privileges and immunities clause indicated that "[n]o State was willing to permit another State to determine who should or should not be admitted as one of its citizens, and entitled to demand equal rights and privileges with their own people, within their own territories," 60 U.S. (19 How.) at 417, Chief Justice Taney was following in the footsteps of Madison and Joseph Story, see 2 J. STORY, Commentaries on THE Constitution $\$ \S 1805-1806$ (5th ed. 1891). Accord, J. HuRd, supra, § 632. But see D. FeHRENBACHER, supra, at 344-46.

Since the adoption of the fourteenth amendment, which overruled Dred Scott by making "[a]ll persons born or naturalized in the United States and subject to the jurisdiction thereof . . . citizens of the United States and of the state wherein they reside," U.S. CoNsT. amend. XIV, $\S 1$, the distinction between state and national citizenship is of greatly reduced importance, as state citizenship generally derives from national citizenship with the addition of residence. See The Slaughter-House Cases, 83 U.S. (16 Wall.) 36, 72-74 (1873). For purposes of article IV, section 2, the distinction could only matter where a United States citizen had not yet established bona fide residence in a state or where an alien is nonetheless a state citizen. (The states are free to extend the grant of state citizenship to aliens, at least for 
state residents shows that two groups equally ineligible for participation in state decision making have been thought to have different claims to the state's public resources. The disenfranchised resident currently is thought to have a greater claim than the disenfranchised nonresident. Significantly, one of the reasons often given for the in-state alien's entitlement is that he is subject to state taxation. ${ }^{163}$ We come, then, to the question of whether the comparative tax (and other) obligations of residents and nonresidents justify the use of residence distinctions in the allocation of state-funded public resources.

Here the underlying constitutional assumptions of our federal structure support state power to favor residents. State authority governs only within the state's fixed territorial boundaries. As a result, a state may tax and regulate residents based on the fact of residence within the state, while nonresidents as a class are immune. ${ }^{164}$ Only those nonresidents who engage in taxable activity

internal purposes. E.g., Crosse v. Board of Supervisors of Elections, 243 Md. 555, 221 A.2d 431 (1966) (holding an alien a state citizen eligible to hold the office of sheriff).) Whether a state can freely discriminate against out-of-state aliens whose states of residence nonetheless consider them state citizens is thus still an open question.

But it probably need not be decided. Wholly aside from whether it is national or state citizenship-or both-that matters for purposes of article IV, section 2, and even if one accepts the assumption that no alien may claim the protection of the clause, aliens' current fourteenth amendment rights to equal protection should render their exclusion from the coverage of the comity clause meaningless. Out-of-state aliens might be singled out for unfavorable treatment in two cases-where article IV, section 2 would prohibit discrimination against out-of-state citizens, and where a state may constitutionally disfavor all nonresidents but chooses only to disfavor out-of-state aliens. In either case the state is relying on the status of alienage, not nonresidence, to justify the discrimination. The out-of-state alien can claim justifiably that he is worse off than the out-of-state citizen, and that the line drawn between his class and the class of out-of-state citizens is an invidious classification violating equal protection. The out-of-state alien, like the in-state alien, is part of a politically powerless group historically subjected to discrimination, "a prime example of a "discrete and insular' minority for whom . . . heightened judicial solicitude is appropriate." Graham v. Richardson, 403 U.S. 365, 372 (1971). Even where the Court has been less solicitous of discrimination against aliens, see notes 153,160 supra, it is because of perceived attributes of nonmembership in the political community of the state. In this regard, out-ofstate citizens and out-of-state aliens stand on the same footing. Thus the equal protection clause requires that out-of-state aliens be treated on a par with out-of-state citizens. This makes the exclusion of aliens from the protection of article IV, section 2, of no practical significance.

${ }^{2 e s}$ E.g., Graham v. Richardson, 403 U.S. 365, 376 (1971) ("Aliens like citizens pay taxes and may be called into the armed forces. . . . There can be no 'special public interest' in tax revenues to which aliens have contributed on an equal basis with the residents of the State.").

106 New York ex rel. Cohn v. Graves, 300 U.S. 308, 313 (1937); see J. NowAK, R. RoTUNDA \& J. Young, supra note 46, at 313-15, 316-17; Barrett, State Taxation of Interstate Commerce- "Direct Burdens," "Multiple Burdens," or What Have You?, 4 Vand. L. Rev. 
within the state are subject to the state's taxing power. ${ }^{165}$ Even as between residents and the subclass of nonresidents who enter the state, the nonresidents are immunized from obligations that can be imposed on residents. Residents may be taxed on income wherever earned, ${ }^{168}$ whereas nonresidents may be taxed only on income earned within the state. ${ }^{167}$ In addition, although a state is constitutionally free to tax residents for in-state activity without having to impose the same or any tax on nonresidents engaged in the same in-state activity, ${ }^{168}$ the opposite is not true. Nonresidents, by virtue of the privileges and immunities clause, and nonresident business, by virtue of the commerce clause, ${ }^{169}$ may not be taxed on instate activity unless residents or resident business are subject to at least equal taxation. ${ }^{170}$ The vulnerabilities of residents and the immunities of nonresidents together support the use of residence classifications as a proxy for determining who provided the resources to create the state's public goods.

To be sure, the correlation between residency and those who contribute to state revenues is not perfect. The states can and do levy taxes on nonresidents engaged in business within the state and on in-state sales to nonresidents; ${ }^{171}$ they charge nonresidents who utilize state services or purchase state goods; and some states receive indirect contributions from taxes nonresidents pay to the federal government, which are then redistributed among the states through federal spending programs. Indeed, if a state taxes residents at redistributive levels, it may tax nonresidents engaged in the same activity at those levels, ${ }^{172}$ so that it is not even true that

496, $502-03$ (1951).

${ }_{165}$ See, e.g., Shaffer v. Carter, 252 U.S. 37 (1920).

${ }^{168}$ E.g., Lawrence v. State Tax Comm'n, 286 U.S. 276 (1932). See also sources cited note 164 supra.

${ }^{167}$ See Hellerstein, Some Reflections on the State Taxation of a Nonresident's Personal Income, 72 Mrch. L. REv. 1309, 1312, 1318-19 (1974).

${ }^{168}$ E.g., Allied Stores of Ohio, Inc. v. Bowers, 358 U.S. 522 (1959).

${ }^{160}$ Because most interstate business is conducted in corporate form, and corporations are not "citizens" within the meaning of the privileges and immunities clause, see note $\mathbf{4 7}$ supra, nonresident businesses normally will invoke the commerce clause.

${ }_{170}$ With regard to the privileges and immunities clause, see Austin v. New Hampshire, 420 U.S. 656 (1975); Travis v. Yale \& Towne Mfg. Co., 252 U.S. 60 (1920); Ward v. Maryland, 79 U.S. (12 Wall.) 418 (1870). As to the commerce clause, see, e.g., Hale v. Bimco Trading, Inc., 306 U.S. 375 (1939); I.M. Darnell \& Son Co. v. City of Memphis, 208 U.S. 113 (1908); Welton v. Missouri, 91 U.S. 275 (1876).

${ }^{171}$ See generally L. TRIBE, supra note 46 , §§ 6-14 to -19 .

172 See Hellerstein, supra note 167, at 1322 \& n.73. Professor Hellerstein's article provides a good discussion of the separate, and harder, question of whether a state may calculate the rate at which a nonresident's in-state income should be taxed by including income 
nonresidents can be made to pay only for their share of the state services they use. Finally, there may be many residents who do not contribute any taxes to the state treasury, and many others who contribute less than some nonresidents.

These imperfections, however, do not destroy the general validity of using residence to approximate the group responsible for creating the state's benefits. Residents may be compelled to contribute; if some are not taxed, it is only because they cannot pay, or because the representatives of the resident group have decided to grant them an exemption. By contrast, nonresidents as such are entirely immune from compulsory exaction. It is only taxable activity in the state that permits the state to impose a levy. Moreover, that some nonresidents may contribute to the state treasury at most supports an argument that those nonresidents who have paid in more than they have received back may claim a share of other state resources. It will not support a general claim of entitlement to state-funded benefits by nonresidents. Theoretically, a court might allow a nonresident to prove that his contributions to the state's coffers exceeded the costs of state services rendered to him and then either reduce his tax bill or grant him a right to share in the other state programs he has been forced to support. The courts thus far have been unreceptive to this sort of individual accounting, ${ }^{173}$ however, no doubt because of the difficulty of assigning prices to the often intangible state benefits received by the nonresident taxpayer. In the absence of such individualization, it is appropriate to treat residents as the group funding those services that nonresident taxpayers do not inherently use in their in-state activity. ${ }^{174}$ Again, that some nonresidents may pay taxes is no reason to require the state to treat all nonresidents on a par with residents. In sum, when a state uses state revenues to create public goods and services, it has a prima facie justification for allocating those resources to state residents (either preferentially or exclu-

earned outside the state. The point here is that even if the state determines the tax rate by looking to in-state activity only, that rate may be a redistributive rate in the sense that the nonresident taxpayer pays more in taxes than he receives in state benefits (as long as residents are equally taxed).

${ }^{173}$ E.g., American Commuters Ass'n v. Levitt, 405 F.2d 1148, 1152-53 (2d Cir. 1969); Stephan v. State Tax Comm'n, 245 A.2d 552 (Del. 1968), cert. denied, 394 U.S. 573 (1969).

${ }^{174}$ Nonresident taxpayers do, of course, receive the benefits of those public goods (like a climate of law and order) from which they cannot feasibly be excluded, see M. OLson, ThE Logic or Collective Action 14-15, 36-43 (1965), as well as benefits from which they cannot legally be excluded, like highways. 
sively), simply because residents as a class combined to establish them, and nonresidents as a class did not. ${ }^{175}$

\section{The Limits of Resident Preference in the Public Sector}

That the states can assert a strong claim to limit state-funded programs to residents should not mean that nonresident claims of access to these programs must always yield, regardless of the circumstances. Because state power to discriminate against nonresidents, even in the state's public sector, is at odds with the constitutional goals of national unification and an open economy, it is necessary to decide whether the objectives of interstate equality or the purposes of state government shall prevail in any particular context. Special circumstances may argue in favor of nonresident access to certain state-established services.

The appeal of a nonresident claim of access to state-created benefits is likely to vary in accordance with both the extent of the burden imposed on the state if nonresidents must be served and

178 This affirmative case for state freedom to favor residents in the disposition of statecreated benefits precludes equating issues of resident preference in the public sector with those arising when the states impose resident preference requirements on the private sector. Professor (now Justice) Linde, one of the first to pay serious attention to these problems, sought to minimize the differences between public and private sector resident preference by emphasizing that, particularly in the welfare state, nonresidents lose similar, and significant, economic and personal opportunities whichever sector the state biases towards residents. Linde, Constitutional Rights in the Public Sector: Justice Douglas on Liberty in the Welfare State, 40 WASH. L. REv. 10, 49-67 (1965). Moreover, he found little reason to draw a distinction allowing Balkanization whenever a state chooses to socialize "the intended means of its economic protectionism." Id. at 59.

On the other hand, Professor Linde acknowledged that the distinction "between state regulation of the private and state operation of the public sector . . . does remain relevant to the state's use of its fiscal resources," and he conceded that "in the selective use of direct subsidy . . . the states perhaps retain some means immune from constitutional attack to let charity, and economic self-help, begin and end at home." Id. at 64. Although a multitude of resident preferences in the states' public sectors could fit comfortably within this concession, Professor Linde apparently did not intend to open the door very wide. See id. at 66-67. But the affirmative claims of state fiscal autonomy, which rest on valid residence distinctions, cannot be shut out so easily.

As for the incentive to socialism that the distinction creates, it seems unlikely in our society that the desire to be protectionist often will outweigh disincentives. More fundamentally, the states should possess significant freedom to enlarge their public sectors if they wish, and as a practical matter that freedom is restricted if residence distinctions cannot be drawn. The Constitution limits state suppression of the private sector, but it also contemplates public sectors of varying designs in different states and thereby precludes a fully open economy. The conflict is inherent in the system, and eliminating the incentive to socialize can be accomplished only by ignoring the constitutional significance of separate state political communities. 
the extent of the burden on nonresidents if access is denied. The less nonresident access interferes with state ability to serve residents, or the greater the harm that would be inflicted on the nonresident by denying access, the stronger the nonresident claim will be. ${ }^{176}$ What follows is an attempt to flesh out these general guidelines and to assess to what degree the specific factors isolated do, in fact, weigh in favor of the nonresident claim.

1. The "Abundant" State Resource. A strong argument can be mounted that one should refuse to acknowledge state power to prefer residents in allocating state-funded opportunities when the nonresident offers to pay the state's full cost of providing the benefit, and when providing it will not prevent a resident from obtaining the benefit. It is one thing to say that when the state's supply is not large enough to satisfy the needs of both residents and nonresidents, the state should be able to prefer those largely responsible for the availability of whatever supply there is. It is quite another to say that if both can be supplied, and the nonresident offers to pay the full cost of the item, denying the nonresident's offer is justified. Discrimination on the basis of residence in the latter case would be gratuitous. In fact, the distinction would be so arbitrary as to violate even the minimum rationality standard of equal protection. ${ }^{\mathbf{1 7 7}}$

In Doe v. Bolton, ${ }^{178}$ the Supreme Court struck down a Georgia residence requirement imposed as a condition of eligibility for either private or public medical care for abortion patients. The denial of access to private sector benefits within the state alone sufficiently justified the Court's holding that the privileges and immunities clause was violated. But while the Court interpreted the ban on both private and public care as not indicating "any policy of preserving state-supported facilities for Georgia residents," it also said "[t]here is no intimation, either, that Georgia facilities are utilized to capacity in caring for Georgia residents."178 The possible implication is that even if the ban had been narrowed to ex-

176 The objective of national unification is threatened not only by nonresident resentment of exclusion from a state's benefits, but also by resident resentment of being forced to share state resources with nonresidents. The extent of the respective burdens thus affects the balance from two perspectives simultaneously.

177 Even when a residence classification is immune from review under the privileges and immunities clause, the equal protection clause nonetheless applies. Baldwin v. Fish \& Game Comm'n, 436 U.S. 371, 388-91 (1978).

278410 U.S 179 (1973).

179 Id. at 200. 
cluding nonresidents only from public hospitals, nonresident access would have been required anyway as long as the hospitals were not filled to capacity.

Unfortunately, a state-provided service that is not limited in supply exists only hypothetically. Money is always a scarce resource for government. If the state could not be sure of recouping from the nonresident all costs of supply, but was required to serve nonresidents, it might well adopt the alternative of not providing the service to anyone and saving the money for another use. This provides a nonarbitrary reason for denying nonresident access. Furthermore, even if the state could recoup the full financial cost, other, nonfinancial costs of extending state services to nonresidents could make the denial of nonresident access rational. Take the case of the public hospital, for example. The nonresident offering to pay the full costs of care appears to have a strong claim to access when there is an excess of beds over current resident demand. The state might nonetheless rationally argue that it is justified in denying nonresident access either because it wishes to reserve excess capacity for emergencies, or because it wants to provide the best possible care to its residents, and the more crowded the hospital is, the lower the quality of care. Similarly, one could say that total exclusion of nonresidents from state highways is unjustified because there is enough room available to serve both residents and nonresidents. But increases in traffic can impose nonfinancial costs that the state might reasonably want to avoid, so that nonresident access would require spending more state resources to provide more highways.

Despite the inaccuracy of positing a state resource so abundant that allowing nonresident access would not limit state flexibility to service residents, however, there is a natural inclination to think in terms of immediate availability and thus to accord greater weight to the claim of the nonresident seeking nonexclusive access to state services than to the nonresident's claim to a state resource that is available only for one individual's use. ${ }^{180}$ The nonresident's claim for the last public hospital bed at a time when demand exceeds supply has less appeal than a similar claim made when beds are available and the state's reason for denying access is

${ }^{180}$ Cf. Gilmore v. City of Montgomery, 417 U.S. 556 (1974) (finding it easier to uphold federal court injunction insofar as it prohibited a city from allowing segregated private schools and affiliated groups exclusive access to public recreational facilities than insofar as it barred the city from granting such groups nonexclusive access to the same facilities). 
to improve the staff-patient ratio. Whenever the supply of a public good seems ample enough to satisfy both resident and nonresident demand, the nonresident claim of access will seem strong. Before approving nonresident exclusion in such a case, the state should at least be required to come forward with an explanation of why nonresident purchase of a seemingly abundant public service would frustrate a deliberate state policy. If the state does so, the "abundance" may turn out to be more apparent than real. If it does not, the discrimination should be found unjustified and invalid. Evaluation of the nonresident's claim of abundance will depend, therefore, not only on just how abundant the state's resource is, but on the state's true reasons for denying nonresident access. In short, relative abundance of the public sector resource may lead to favoring nonresident access; how strongly, if at all, will depend on a thorough examination of the reasons for the state resident preference.

2. The Nonresident's Need for the State-Created Resource. A state's presumptive right to exclude nonresidents from statefunded services should also be rebuttable when the effect of exclusion on nonresident opportunity is unusually severe. At some point, the effect of nonresident access on the state's fiscal autonomy will pale beside the effect of state discrimination against nonresidents on the national unification, free-trade, and nationwide individual opportunity objectives of the Constitution's interstate equality provisions. When that point is reached, the states' legitimate claim to serve their own residents must give way to the more important claim of national solidarity and opportunity.

Knowing when that point is reached requires an assessment of the importance to the nonresident of access to the state-provided program in question. That requires, in turn, an assessment of the intrinsic importance of the benefit sought, its importance as a means of assuring the nonresident access to other opportunities within the state to which he is clearly entitled, and the extent to which the benefit is unavailable from other sources because the state has a monopoly. The overall strength of any nonresident claim will depend on the combined strength of each element. Inevitably, individual judgments of importance and availability will differ, as will individual judgments of how strong the nonresident's claim must be before the otherwise justified favoritism towards residents must yield. Nevertheless, it is desirable to explain these factors as fully as possible.

The inquiry to be pursued here, with its focus on the impor- 
tance of nonresident access to state-funded programs, may appear to be much like the fundamentality doctrine in the Supreme Court's privileges and immunities clause jurisprudence, a doctrine criticized earlier in this article. ${ }^{181}$ But the point actually is different. The fundamentality doctrine requires the nonresident to show that the in-state opportunity sought, whether state-created or not, is "basic to the maintenance or well-being of the union" before the clause even applies. ${ }^{182}$ The point here is that the state always must justify residence discrimination. Even when the state has a prima facie justification for favoring residents because the nonresident seeks access to state-financed opportunities, the nonresident may nonetheless overcome that justification if the opportunity denied is sufficiently important. Moreover, the fundamentality doctrine appears to concentrate on the importance of the opportunity alone, without taking into account whether it is uniquely available within the state. ${ }^{183}$ The purpose, effects, and scope of operation of the fundamentality doctrine are thus radically different from those of the present inquiry.

a. The intrinsic importance of the state-created benefit. All other things being equal, the strength of the nonresident's claim to access will vary with the significance of the opportunity sought. The nonresident's claim to emergency medical, police, and fire protection services within the state surely stands on a different plane than a claim of access to public golf and tennis facilities, or to public education or employment, even assuming the equal existence or nonexistence of in-state alternatives in each case. With the possible exception of emergency services, the inherent significance of the state benefit alone probably will not overcome the state's justification for resident preference. That is particularly true where the choice will be between serving only residents and not serving anyone at all, or where the service will be readily available from other sources. In the first case, forcing the state to serve nonresidents results in depriving residents of the service. The importance of the interest could actually cut against the nonresident claim here. In the second case, although the service or benefit itself may be important to nonresidents, having the state provide it is not, because alternate sources of supply exist. But, although the intrinsic importance of the benefit usually is not a strong factor by itself, it is

${ }^{281}$ See text and notes at notes 88-118 supra.

${ }^{182}$ Baldwin v. Fish \& Game Comm'n, 436 U.S. 371, 388 (1978).

${ }^{183}$ See id. at 374-76 (opinion of the Court); id. at 394 (Brennan, J., dissenting). 
relevant to evaluating the overall weight to be given the nonresident's claim.

b. The ancillary state benefit needed to provide nonresident access to opportunities whose availability is guaranteed. Some public services may be important to nonresidents in order to ensure equality of access with residents to other public or private sector opportunities whose availability to nonresidents is guaranteed. As noted earlier, the Supreme Court zealously enforces the rights of nonresidents and nonresident business to equal access to the private sector. ${ }^{184}$ Those rights would not be meaningful if statefunded programs necessary to private sector access could exclude nonresidents. For example, if state roads could be closed to all but residents, or if state-owned public utilities could limit in-state customer service to state residents, then nonresident freedom to trade or deal with residents, or to live in one state and operate a business in another, or even to pass through one state to get to another, would be drastically curtailed. Although state revenues may be responsible for the existence of the roads or utility services, state fiscal autonomy cannot justify such severe collateral effects of nonresident exclusion.

That a public resource is ancillary to nonresident enjoyment of constitutionally guaranteed opportunities, however, does not automatically override state authority to favor residents. Here again, whether the state has the ability to serve both residents and nonresidents is relevant, as is whether the nonresident can find the needed resource elsewhere.

But one might sensibly require less of a showing of abundance or state monopoly to uphold a right of nonresident access if the benefit in question is of intrinsic or ancillary importance, or both, than if it is neither. Thus, nonresidents should be guaranteed instate police and fire protection and general access to state courts, ${ }^{185}$ even though these services are funded from the state's

184 See text and notes at notes 14-18 supra.

$18 s$ The best discussion of the privileges and immunities clause with respect to nonresident access to state courts is Currie \& Schreter, supra note 9, at 1379-89, reprinted in B. Currie, supra note 9, at 511-23. See also Simson, supra note 126, at 398-99. Professor Currie was critical of Justice Holmes's statement in Douglas v. New York, N.H. \& H.R.R., 279 U.S. 377, 387 (1929), that " $[t]$ here are manifest reasons for preferring residents in access to often overcrowded Courts, both in convenience and in the fact that broadly speaking it is they who pay for maintaining the Courts concerned." In response, Currie pointed to highways and police protection, and asserted, in agreement with the conclusions reached in this article, that "the fact that local residents or citizens primarily bear the cost of local facilities does not of itself justify refusal of their use to citizens of other states." Currie \& Schreter, 
general revenues, and even though it may be possible to secure substitutes, because these services are integral to the enjoyment, on the same terms as residents, of other in-state opportunities open to nonresidents. Under those circumstances, the interstate equality claim should supersede the claim of state freedom to confine state spending for the benefit of residents.

c. The state-created benefit unavailable elsewhere: the equality obligations of monopoly power. Any assessment of the impact of state resident preference policies on nonresident opportunity would be incomplete without consideration of whether, and to what extent, the benefit the state wants to deny the nonresident could possibly be obtained from another source. When the nonresident's alternatives are limited or nonexistent, the severity of exclusion from the state's program should weigh heavily, and often dispositively, in favor of the nonresident's claim of access.

The argument that a lawful monopolist should have less freedom than others to discriminate in selecting those with whom to deal has been accepted in a number of nonconstitutional business contexts. Thus, when the states choose to treat private utilities with natural monopolies as regulated industries, they typically require them to refrain from discrimination in customer selection. ${ }^{\mathbf{1 8 6}}$ At common law, businesses clothed with a public interest were subject to similar duties of nondiscrimination. ${ }^{187}$ Under federal antitrust law, rules of nondiscriminatory access have even been imposed on business firms that undertake lawful concerted activity to develop facilities that amount to natural monopolies. ${ }^{188}$

The analogy between state refusals to make state-created re-

supra note 9 , at 1380 , reprinted in B. CuRRIE, supra note 9 , at 511-12. He deemed it a truth that the Privileges and Immunities Clause requires a state to open the doors of its courts to citizens of other states who assert claims against local residents and citizens, even on causes of action predicated upon the law of another state, if it would allow its own citizens to assert such a cause of action.

Id. at 1384, reprinted in B. CuRrIe, supra note 9, at 516. Nonetheless, Currie also considered "the constitutionality of the doctrine of forum non conveniens . . . firmly established," $i d$., and he agreed that a state should be able to turn away litigation when none of the parties is a resident, because in doing so the state is respecting another state's greater interest in the litigation and is preventing the use of its own courts for purposes of harassment, id. at 1384-85, reprinted in B. CURRIE, supra note 9, at 515-16. I do not mean to question the validity of the forum non conveniens doctrine either.

${ }^{28}$ See W. Jones, Regulated Industries 288 (2d ed. 1976).

${ }^{182}$ See RESTATEMENT OF TORTS $§ \S 762-765$ (1939).

188 See Otter Tail Power Co. v. United States, 410 U.S. 366 (1973); Associated Press v. United States, 326 U.S. 1 (1945); United States v. Terminal R.R. Ass'n, 224 U.S. 383 (1912); L. Sullivan, Handbook of the Law of ANTtTrust $\$ 48$ (1977). 
sources available to nonresidents and biased customer selection policies of private businesses is certainly not perfect. The legitimate purposes of private enterprise are more limited than those of the states, and it is therefore more likely that discriminatory refusals to deal by private organizations will reflect arbitrary, anticompetitive, or retaliatory motives than it is that state refusal to deal with nonresidents will do so. The analogy may be closer when the state resource in question is the product of a state business enterprise, but even then the state's purpose, unlike that of private business, usually is not exclusively to make a profit. Moreover, the private business does not have the state's presumptive justification for refusing to make state-created benefits available to nonresidents.

On the other hand, although the state's reason for discriminating against nonresidents may seem less blameworthy than the motive for a similar decision by a private firm, the effect on the excluded party is as severe when the state is a monopolist as when a private organization is. It is the possession of monopoly power that transforms the private firm that is free to discriminate into a firm that is subject to a duty of providing nondiscriminatory access. In large part, the reason is that discriminatory exclusion would leave the excluded party without recourse and would unduly limit opportunities. Preventing state limitation of nonresident opportunity is, of course, a prime objective of the commerce and privileges and immunities clauses, and when the state is in a monopoly position its power to disadvantage nonresidents relative to residents can be overwhelming. The combination of the Constitution's special concern for nonresidents as a class and the widespread, traditional public policy against discriminatory distribution of monopolized benefits therefore tends to support a principle forbidding state residence discrimination in the distribution of state-monopolized resources.

Even if one accepts this general rule, however, there is ample room for debate about what level of monopoly power should trigger the equality obligation. That level will vary, of course, depending on the abundance, and the intrinsic or ancillary importance, of the state resource. ${ }^{189}$ But some inquiry into just how foreclosed the

189 Thus, even if the state does not have a complete monopoly of police and fire protection services within the state, or of the judicial resolution of nonresident disputes with residents, the importance of these services, together with the degree of monopoly power possessed by the state, argues strongly in favor of an equality obligation. See text and note at 
nonresident's alternatives are is also a central feature of the calculus. Measurement of monopoly power requires some sensitivity to geographic and product markets, as well as to the monopolist's market share. ${ }^{190}$ In short, it is necessary to determine the amount of monopoly power present in a particular instance as well as the amount necessary to impose the obligation of equality. In the context of state resource monopolies, these factors suggest a number of relevant issues. When considering the nonresident's alternatives, should the availability of the resource in the nonresident's home state matter, or only the availability in the private sector of the state wishing to deny him access to the public resource? What resources similar in function to the resource sought should be considered acceptable substitutes for the purpose of measuring availability? Does it matter whether no realistic alternative is possible, as in the case of natural monopolies, or whether other sources are possible but presently unavailable?

Some examples will demonstrate the relevance of these questions. First, consider the most extreme case, where the state has a complete monopoly and for legal or practical reasons no other source of supply is feasible. The state highway, built and maintained with state funds, is perhaps the most obvious resource that the private sector will not duplicate. The public utility owned and operated by the state is another natural monopoly that effectively precludes private sector competition. In both cases, the nonresident must have access to the state-created service if there is to be any in-state access at all. The geographic market must be confined to the state if there is to be any access to in-state opportunities that must be available to nonresidents; no reasonable substitutes for the state service are available. The case for nonresident access is at its strongest.

The nonresident's case for a right to use state-operated transportation systems arguably is weaker. Even if the state has a natural or legal monopoly on bus or rail service, the availability of private motor vehicle transportation may weaken the nonresident's claim. That would be true only if one considered the alternative an adequate substitute; given the importance of transportation, this seems doubtful. But the point is that product definition may have some bearing on whether the state's exclusion of nonresidents should be permitted. If private and public bus companies freely 
competed over the same routes at reasonable intervals, the nonresident claim would certainly be weakened due to the decrease in the state's monopoly power.

There also are strong elements of state monopoly in the provision of police and fire protection within the state. The existence of private counterparts to public police and fire departments arguably leaves the nonresident free to look elsewhere for in-state protection, at least if he is wealthy enough; but the importance of these services, together with the infeasibility of private alternatives, should suffice to establish his entitlement to receive them from the state.

In each of the preceding examples, the availability of the desired benefit in the nonresident's home state is irrelevant. That the nonresident is entitled to use the highways, utility service, public transportation, or police and fire protection within his home state is no help to him while he is elsewhere. There are other cases, however, where home state availability does appear to be relevant. It could be argued that the relevant geographical focus should always be the state wishing to deny state-created resources to the nonresident, because the point of the constitutional guarantees of interstate equality is to provide protection for the resident of one state in every other state. But once the premise that the state is presumptively justified in using state revenues for the benefit of residents alone is accepted, it seems sensible that, although that justification can be overridden by a claim of exceptional nonresident need, all sources potentially available to alleviate that need should be considered, including those available in the nonresident's home state. ${ }^{101}$ An assessment of the adequacy of the home-state alternative will, of course, be required, and the fact of distance may often make the alternative inadequate. But the alternative may sometimes be viable. For example, suppose a state has only public hospitals or state-operated liquor stores. If a nonresident seeks nonemergency medical care or attempts to purchase liquor, should the in-state monopoly establish his right to be served even though similar care and commodities are available in his home state? Cer-

101 Available sources in third states may also be relevant. One must be careful to include only such states as are realistically accessible to the nonresident, or in other words, only those within the relevant geographic market. Moreover, it is problematic whether one state's right to exclude nonresidents from state-created benefits should be built upon another state's willingness to include nonresidents, because the other state may decide to claim a similar right of nonresident exclusion. The nonresident's home state by definition is unable to exclude him from state benefits on that basis. 
tainly the nonresident's claim is stronger if there is no private instate alternative, just as it is if there is no home-state alternative, although in any given case other factors may make the state fiscal autonomy claim strong enough to prevail. ${ }^{192}$ The state's creation of unique resources imposes greater equality obligations than its creation of resources also found in other states.

Application of the principle that monopoly power often carries with it duties of nondiscriminatory access requires careful individualized evaluation in each case. Many of the difficulties that plague antitrust law will be equally troublesome in this context as well. But if it is important enough to make the inquiry to reach appropriate results in the field of antitrust, it is also important enough in the enforcement of the commerce and privileges and immunities clauses.

\section{Unconditional Allocations of State Resources}

Bearing in mind the basic approach developed in Part II to delineate the contours of state power to favor residents over nonresidents, the next two parts of the article evaluate the constitutional validity of residence discrimination in the distribution of a wide range of state-owned resources. Two different forms of state resident preference will be addressed. The first, the subject of this part, is when the state gives its residents exclusive or preferred access to state resources without exacting any promises from those who deal with the state to implement other resident preferences. Accordingly, this part centers on the two-party relationship between the state and those with whom it will deal directly and unconditionally. In the next part, preference schemes that condition eligibility to participate in public programs on the recipient's willingness to favor residents in independent transactions will be considered.

\section{A. The Expenditure of State Funds}

When the states spend money directly on private parties, either through subsidies or through payments for goods or services, they would appear to have the strongest justification for preferring

102 Assuming an in-state monopoly and home-state availability in both examples, the greater importance of access to even nonemergency medical care than of access to alcoholic beverages may well limit state power to exclude nonresidents in the former case, but not in the latter. 
residents as the recipients of those funds. The collection of state revenues to serve state residents is at the core of the purposes of state political organization, and money is the paradigmatic fungible resource that is not monopolized by one or a limited number of states. Moreover, monetary resources are finite; making funds available for one purpose, or for one group, makes them unavailable for use by another.

Nonetheless, because of the inherent tension between the goals of interstate equality and the basic assumptions of the states as separate political communities, some state spending schemes that favor residents have been thought more troublesome than others. I have already indicated that inability to limit eligibility for state subsidy programs to residents often would eliminate the state's freedom to choose whether to have subsidy programs or not. ${ }^{193}$ Whether this is undesirable in the special context of subsidies to resident business, however, as it so clearly is in the context of welfare assistance, remains to be considered. After that issue is examined, the remainder of this section deals with the general problem of state purchases of goods and services, and then with the question of state employment.

1. State Subsidies to Private Business. If a state provides local industry with financial subsidies to improve its interstate competitive position, or to induce out-of-state businesses to relocate within the state, does the subsidizing state's preference for resident business violate the antidiscrimination core of the commerce clause? Before that question can be answered, it must be refined by taking account of the nature of the subsidy and its relationship to the comparative tax obligations of resident and nonresident business. The issue is best framed by asking whether a state is free to grant direct subsidies to in-state business only, assuming the state does not tax the in-state activity or income of either resident or

\footnotetext{
193 See text at note 150 supra. Not all financial assistance programs present "freerider" problems. California, for example, provides assistance to residents injured as victims of crime, but does not pay nonresidents who are victimized while in the state. It seems unlikely that requiring California to treat persons criminally injured in the state without residence distinctions would lead to any influx of crime victims. Nonetheless, the restriction of assistance to residents follows readily from the fiscal autonomy interests of the state. The program's restriction was recently upheld over the objection of a nonresident shot on vacation in San Francisco, Ostrager v. State Bd. of Control, 99 Cal. App. 3d 1, 160 Cal. Rptr. 317 (Ct. App. 1979), appeal dismissed, $101 \mathrm{~S}$. Ct. 53 (1980), although on the less satisfactory ground that the privileges and immunities clause did not apply because, following Baldwin, "receiving compensation as a crime victim from the state in which the crime occurred is [not] a basic right." Id. at $6,160 \mathrm{Cal}$. Rptr. at 320 .
} 
nonresident business. The qualification is necessary, because it is clear that the states are forbidden to tax out-of-state businesses more heavily than in-state businesses, ${ }^{194}$ that they may therefore not allow resident businesses tax deductions or exemptions unavailable to nonresident businesses, ${ }^{198}$ and that the same impermissible result would be produced if resident and nonresident businesses were equally taxed but only resident businesses received cash subsidy rebates.

The issue is not whether a state that does not tax nonresident business, but generally does tax resident business, may give tax breaks or cash subsidies to selected resident industries. In that situation, the state is doing no more than lowering its tax rate for some in-state businesses relative to others. Its action does not directly disadvantage out-of-state businesses. Although the favored industry may now be relatively better off than competitiors in other states with higher tax rates, this is an implicitly sanctioned consequence of allowing each state to choose independently whether and at what rates to impose taxes. As noted previously, ${ }^{196}$ the states' independent taxing authority necessarily departs from the ideal of a true free-trade area, but that departure is an underlying assumption of our federal structure.

The question here is whether the implicit assumptions of federalism also sanction direct subsidies to local business that, although they do not mask discriminatory taxation of foreign businesses, do more than lower the taxes of resident business. ${ }^{197}$ The subsidy issue frequently is posed in connection with Justice Cardozo's opinions in Baldwin v. G.A.F. Seelig' ${ }^{188}$ and Henneford v. Silas Mason Co. ${ }^{189}$ In Baldwin, the Supreme Court held that a state could not insulate in-state milk producers from out-of-state competition by establishing a minimum price that in-state retailers had to pay their suppliers, wherever situated. In Silas Mason, the Court allowed a state that imposed a domestic sales tax to impose

194 See text and notes at notes 169-170 supra.

${ }^{195}$ See Travis v. Yale \& Towne Mfg. Co., 252 U.S. 60 (1920).

198 See text following note 147 supra.

197 The distinction is between businesses domiciled in the state and businesses domiciled elsewhere. If a state denied eligibility for a subsidy to businesses domiciled in the state, but owned by the residents of other states, a different issue would be presented. Given the obligations of such businesses to the state, subsidy discrimination among resident businesses on account of the residence of their owners should not be permitted.

188294 U.S. 511 (1935).

190300 U.S. 577 (1937). 
a compensating use tax in the same amount on goods purchased in other states but used in the taxing state. The cases are reconcilable. The minimum price scheme entirely wiped out the competitive price advantage previously enjoyed by out-of-state producers as a result of their greater efficiency. The use tax, on the other hand, only eliminated a competitive advantage enjoyed by nonresident sellers as a result of the taxing state's sales tax, which necessarily (although certainly not intentionally) placed resident sellers at a competitive disadvantage relative to nonresident sellers domiciled in states with no or lower sales taxes. Under this commonly held view, ${ }^{200}$ the commerce clause is not a barrier to all state laws that affect the flow of commerce towards local, and away from out-ofstate, business-for the constitutionally permissible use tax was expressly designed to keep domestic purchasers from buying where lower tax burdens caused overall prices to be cheaper. Instead, as Justice Cardozo put it in Baldwin, the commerce clause precludes state efforts "designed to neutralize advantages belonging to the place of origin." 201 In Silas Mason, the advantage that nonresident sellers possessed because of the sales tax did not belong to the place of origin of their goods. It was, rather, attributable to the taxing state. Thus, Cardozo could say of the use tax that "equality and not preference is the end to be achieved."202

Ernest Brown objected to Cardozo's analysis on the ground that the relevant issue was "not preference, but protection," plying that protection of local merchants with the effect of limiting resident consumer access to cheaper out-of-state goods was well within the concerns of the commerce clause. What, then, of subsidies to local business only? To turn Professor Brown's phrase around a bit, they are not only protection-they are also preference. Their objective is to protect local industry against the forces of the interstate market by nullification of competitive advantages available elsewhere. The method of accomplishing that objective is to prefer business domiciled in the state in the allocation of state funds. Unlike the tax in Silas Mason, the direct subsidy seeks to do more than offset the competitive disadvantages to resident business arising from local tax burdens. It seeks to reduce the competitive edge possessed by out-of-state business whether derived from

\footnotetext{
200 See L. Tribe, supra note $46, \S 6-16$, at 359.

202294 U.S. at 527 (emphasis added).

202300 U.S. at 586.

${ }^{208}$ Brown, supra note 4, at 235.
} 
lower tax rates, productive efficiency, or anything else. The result of an effective local subsidy program will be the same as that of a tax or minimum pricing scheme-to distort the competitive interstate market and thereby alter consumption patterns. The longterm effects are likely to be incompatible with nationwide economic efficiency.

These considerations argue strongly against the constitutionality of direct subsidies. But there are substantial arguments on the other side. First, unlike the tax or price regulation that dulls the competitive edge of out-of-state business by raising the price of its products to resident consumers, the subsidy diverts trade to businesses domiciled in the subsidizing state by allowing them to lower their prices. The effect on out-of-state businesses may be similar, but, at least in the short run, subsidies do not threaten-and may even enhance-consumer access to cheaper goods in the interstate market, thereby alleviating one of Professor Brown's concerns about Silas Mason. ${ }^{204}$

Second, following the distinction between Baldwin and Silas Mason and the theory advanced in this article, it may be said that the competitive advantages lost to producers in State $B$ by virtue of a subsidy to domestic producers given by State $A$ do not belong to State $B$, the "state of origin," but rather to State $A$. Just as State $B$ 's producers may not complain under the commerce clause of private productivity gains in State $A$ that make State $A$ producers more competitive, so the subsidy may be taken as another one of the permissible conditions that give State $A$ whatever competitive advantages it affords. To be sure, a state that discriminates against out-of-state goods through tax or price regulation mechanisms harms not only nonresident merchants, but also the state's own consumers, who lose access to cheaper goods. But the subsidy is only different in that it burdens the state's taxpayers, or those residents who would benefit from alternative uses of state funds, or some of both, instead of the state's consumers, as it harms the nonresident merchant. In light of the overlap between these groups, the distinction may seem insubstantial. But to strike down a state expenditure of funds collected for the primary purpose of

204 See id. But see L. TrIBE, supra note 46, § 6-10, at 337:

Ordinarily, . . . concern with adverse impacts on competitors has not been muted by any principle that, unless harm to consumers is demonstrable, an open economy need not be maintained. On the contrary, the assumption has been, and continues to be, that producers no less than consumers may claim the protection of the implied restraints of the commerce clause. 
serving residents, just because the immediate objective of the expenditure is to attract industry, employment, and commercial prosperity to, or to keep it in, the subsidizing state, would be to interfere with the state's disposition of nonmonopolized public resources-an interest that is not implicated when a discriminatory tax or artificial price regulation is applied to out-of-state goods. ${ }^{205}$

Just as the states are permitted to adjust the level of nondiscriminatory tax they impose on in-state business activity, even if the purpose of the adjustment is to help local business compete in interstate commerce, ${ }^{208}$ so may they claim a right to establish internal spending policies to accomplish the same objective. In the case of either taxing or spending policy, independent state decision-making authority necessarily deviates from the ideal of a freetrade unit. But the American federal structure assumes that there is a difference between a state modifying the burdens or benefits distributed among its own residents and a state setting discriminatory terms on which those outside the state, over whom it has no direct authority, must deal with state residents, even though the effect on interstate relationships may be similar in each case.

2. State Payments to Purchase Goods or Services. The expenditure of state money is not limited to subsidy payments, of course. Much of the state's treasury is spent on the purchase of goods and services for the operation of government. But is there anything about state commercial expenditures that should curtail the power the states normally have to prefer residents in the distribution of state revenues?

205 This argument cannot be carried too far. For example, it would not justify purporting to tax in-state and out-of-state businesses equally and then subsidizing the in-state businesses. As noted above, this practice clearly would amount to discriminatory taxation.

${ }^{206}$ In Boston Stock Exch. v. State Tax Comm'n, 429 U.S. 318 (1977), the Court unanimously overturned an amendment to the New York scheme for taxing stock transfers that discriminated against sales of stock by nonresidents on out-of-state exchanges by reducing the tax otherwise due New York only when the sale took place on the New York Stock Exchange. Even though the preference for in-state sales also advantaged nonresident sellers, Justice White concluded that "a state may [not] tax in a manner that discriminates between two types of interstate transactions in order to favor local commercial interests over out-ofstate businesses." Id. at 335. At the same time, however, he insisted, without elaboration, that the Court's decision

does not prevent the States from structuring their tax systems to encourage the growth and development of intrastate commerce and industry. Nor do we hold that a State may not compete with other States for a share of interstate commerce; such competition lies at the heart of a free trade policy. We hold only that in the process of competition no State may discriminatorily tax the products manufactured or the business operations performed in any other State.

Id. at 336-37. 
Once one accepts the basic premise of Silas Mason and the preferential business subsidy - that state conduct designed to help resident industry attract business is not invalid per se-it is too late to criticize state purchasing policies preferring in-state suppliers for seeking an impermissible objective. Moreover, because the state may not deny the nonresident supplier equal opportunity to offer its goods and services to resident consumers other than the state itself, it normally cannot be said that the state monopolizes in-state sales opportunities.

On the other hand, state commercial payments do not pose the free-rider problem that pure subsidy payments do. Unlike welfare payments or business subsidies, state purchases of equipment and services will be made whether or not a rule of nonresident equality is imposed. Indeed, states without purchasing policies favoring in-state businesses enjoy a greater opportunity to save state funds through competitive bidding on a broader basis.

Still, it is not a necessary condition of state power to favor residents that lack of power to discriminate will effectively eliminate state ability to adopt a program at all (although when that condition is met the state generally will have a stronger case for favoring residents). Although allowing the states to bias their purchasing policies in favor of resident suppliers departs from freetrade principles, opportunities to sell to the state exist only because they were created by the state and its residents. Those opportunities can, therefore, justifiably be limited to the state's residents.

3. State Employment. The Supreme Court has never passed on the validity of a state policy favoring residents for public employment. ${ }^{207}$ The issue tends to be treated more seriously than state preference for resident suppliers, although the state spends money to obtain labor, just as it might spend money to buy goods or the services of independent contractors. Perhaps this is because it is more common to think of eligibility for state employment as a question of state distribution of employment opportunities rather than as a question of state allocation of money. But whatever the more comfortable characterization is, it remains true that the jobs are created by the state for the primary purpose of serving resident interests, using funds collected (largely from residents) for that purpose. When the state hires workers to carry out state programs

${ }^{207}$ See Hicklin v. Orbeck, 437 U.S. 518, 531 n.15 (1978), discussed in note 162 supra. 
and gives resident applicants priority in filling the jobs, it has a dual objective in mind-to get the work done and to subsidize resident employment. Both objectives are constitutionally valid, and the means chosen fit within the previously advanced justifications for state authority to prefer residents.

Professor Simson recently argued that, except "with respect to high elected office," the privileges and immunities clause should be imposed as a bar to favoring residents for public employment. ${ }^{208}$ $\mathrm{He}$ rejected the use of residence classifications as a permissible means of reducing resident unemployment. The reasons he gave were that a priority for residents does not clearly increase resident employment, because the resident might otherwise be employed in the state's private sector anyway, and that the problem of resident unemployment can be addressed "at least as effectively by jobtraining programs and other less drastic means."209

I find neither of these reasons persuasive. Consider, first, a state that deals with resident unemployment by adopting a policy of making the state government the employer of last resort. By definition, only currently unemployed residents will be hired under the program. There is then no reason to fear that the state is drawing residents from the private sector. The public sector resident preference program does achieve an increase in total resident employment, and it does so directly. ${ }^{210}$ Nor are suggested alternatives just as effective. Job-training programs do not increase employment at present, nor do they guarantee that a job will be available when the training is over. Moreover, are we to assume that participation in the state's job-training program may be restricted to residents? If so, it is difficult to see how the educational advantage can be any more easily justified than the employment preference. If not, the suggested alternative is rendered an even weaker substitute for the state's goal of reducing unemployment among residents.

${ }^{208}$ Simson, supra note 126, at 393.

209 Id.

210 It seems clear that a state could not attack unemployment by requiring the private sector to prefer residents in hiring. In Hicklin v. Orbeck, 437 U.S. 518, 526 (1978), Justice Brennan's opinion for a unanimous Court described the argument "that a State may validly attempt to alleviate its unemployment problem by requiring private employers within the State to discriminate against nonresidents" as "an assumption made at least dubious by Ward [v. Maryland, 79 U.S. (12 Wall.) 418 (1871)]." Given the Court's history of protection of nonresident access to the commercial opportunities available in the private sectors of other states, see text and notes at notes 14-18 supra, it is very difficult to imagine the Court upholding such a scheme. 
The state's justification for reserving state jobs for residents may appear somewhat weaker when the advantage given to residents is not limited to the currently unemployed. But appearances can mislead. If the state is in fact drawing residents away from the private sector, that only leaves more opportunities there, where the resident and nonresident are free to compete for the job vacancies. If a resident fills the private sector vacancy, the state has achieved an overall increase in resident employment. If a nonresident fills the vacancy, the state job preference for residents puts the nonresident in a better position than he would have been in had the state chosen not to create the state job and never caused the private sector vacancy. Either the preference is justified or the nonresident is advantaged, not disadvantaged.

It would be meaningless to talk of a requirement of nonresident access when the state has an abundance of vacancies. Every state job is a scarce resource if there is competition for it. Even if a state chooses not to fill a job vacancy for which only nonresidents apply, its justifiable choice is merely to save its scarce financial resources for other uses. But it might plausibly be argued that some state jobs cannot be duplicated in the private sector, and as to these, at least, nonresidents are entitled to equal consideration because of the state monopolization. This argument also fails, however, for the only state jobs that cannot be duplicated in the private sector are those core political positions that are most appropriately reserved to residents because of the political responsibilities of the officeholders to their resident constituents. ${ }^{211}$ In short, the general principle supporting state authority to prefer residents in the distribution of state-created resources applies fully to state employment.

\section{B. State-Created Goods and Services}

Questions of the validity of state resident preference policies arise when a state distributes resources in kind as well as when it spends money. When the state converts its fiscal resources into goods or services that it makes available on a residence-discriminatory basis, the same justification that supports state expenditures favoring residents should apply. The value of state flexibility to serve state residents in a variety of ways, both tested and experimental, strengthens the claim of a state that wishes to convert 
state revenues into programs believed to be beneficial to its constituents. Different rules for state-created goods and services and state payments to residents would unnecessarily narrow the ability of state government to create new ways of serving its people. Except where special circumstances dictate otherwise, the state should be able to reserve in-kind resources created with state funds for its residents. To take just one example, there is no greater reason to restrict state power to limit eligibility for public housing to residents than there is to restrict state power to limit eligibility for welfare payments that can be used to purchase private housing. So long as the state does not monopolize housing construction, public housing projects may be limited to residents. The same analysis is applicable to a multitude of state programs, but two in particular deserve special attention.

1. The Sale of Goods Manufactured by State Enterprise. In the recent case of Reeves, Inc. v. Stake, ${ }^{212}$ the Supreme Court narrowly upheld over commerce clause objections South Dakota's policy of preferring residents as customers of the state's cement plant. Justice Blackmun's general defense of the proprietary exemption from commerce clause scrutiny was criticized earlier. ${ }^{213}$ But later in his opinion, in the course of examining whether the South Dakota policy fell within any "exception" to the "general rule of Alexandria Scrap,"214 he did touch on some of the themes of this article.

Justice Blackmun briefly stated that invalidation of the preference for resident business "would discourage similar state projects, even though this project has demonstrably served the needs of state residents and has helped the entire region for more than half a century," and would rob the state "of the intended benefit of its foresight, risk, and industry."216 It is somewhat exaggerated to suggest that unless the state could prefer residents they would derive little benefit from, and therefore have little incentive to establish, a source of supply they thought the private sector could not be relied upon to provide. Because the state was selling the cement, and because some resident businesses would benefit from the availability of cement even if some nonresidents also would benefit, free-rider problems would not have completely eliminated the incentive to develop a state cement plant. But state rep-

212447 U.S. 429 (1980).

213 See text and notes at notes 79-87 supra.

214 447 U.S. at 440.

s15 Id. at 446 (footnote omitted). 
resentatives probably will consider the extent to which state residents will benefit from a proposed investment of state funds, and the Court therefore should examine the extent of the disincentive to adopting a state program created by a ban on resident preference, whether or not the state program can fairly be described as proprietary.

Justice Blackmun also adverted to the broader justification for resident preference suggested in this article when he rejected the argument advanced by the out-of-state plaintiff that, despite the "proprietary" character of the state program, the resident preference policy was an invalid attempt at protectionism. ${ }^{216}$ The four dissenters were persuaded of the validity of the resident preference with respect to sales for public use, but agreed with the plaintiff that the preference for resident customers in the state's private sector was forbidden economic protectionism-protection of "private economic interests within the State from the forces of the interstate market."212 Justice Blackmun responded by saying that the State's policy was

"protectionist" only in the sense that it limits benefits generated by a state program to those who fund the state treasury and whom the State was created to serve. [This] argument apparently also would characterize as "protectionist" rules restricting to state residents the enjoyment of state educational institutions, energy generated by a state-run plant, police and fire protection, and agricultural improvement and business development programs. Such policies, while perhaps "protectionist" in a loose sense, reflect the essential and patently unobjectionable purpose of state government-to serve the citizens of the State. ${ }^{218}$

This passage should have been the starting point of the Court's opinion. ${ }^{219}$ Justice Blackmun also adverted to the possibil-

216 Id. at 442.

${ }^{217}$ Id. at 447 n.1 (Powell, J., dissenting).

218 Id. at 442 (footnote omitted).

219 With some changes. Justice Blackmun's list of examples perhaps could have been better chosen or more precisely defined. As this article argues, there may be strong reasons to insist on a state's obligation to provide nonresidents within the state with police and fire protection or state-monopolized utility service. Perhaps Justice Blackmun was referring only to a nonresident's claim that these services be provided beyond the state's borders when he so easily asserted the state's power to restrict these services to residents. In addition, the apparent assumption that only residents fund the state treasury is overbroad. See text at notes 171-172 supra. 
ity that the state's possession of monopoly power might have made a difference. He distinguished natural resources from cement and other "end-products of a complex process whereby a costly physical plant and human labor act on raw materials," 220 and he stressed, consistently with an emphasis on monopoly power, that

South Dakota has not sought to limit access to the State's limestone or other materials used to make cement. Nor has it restricted the ability of private firms or sister States to set up plants within its borders .... . Moreover, petitioner has not suggested that South Dakota possesses unique access to the materials needed to produce cement. Whatever limits might exist on a State's ability to invoke the Alexandria Scrap exemption to hoard resources which by happenstance are found there, those limits do not apply here. ${ }^{221}$

In effect, this language amounts to stating that South Dakota had not raised a barrier to entry by competing firms that might supply nonresidents. To be sure, South Dakota possessed a kind of monopoly power simply because it had an available cement supply in a time of shortage. The majority of the Court appears implicitly to have rejected that level of monopoly power as sufficient to require nondiscriminatory selling policies and to have left open the question of whether monopoly power in the sense of unique control of the supply of a resource should trigger obligations of equality. ${ }^{222}$

One would expect a state to have a greater claim to reserve state-financed benefits for residents when other organizations are free to provide similar benefits, even if they have not yet decided to do so, than when the state's control precludes competition. For a majority of the Court, it appears that state interests in fiscal autonomy will prevail over a nonresident's claim of access to state benefits when the state does not have a natural or exclusive mo-

220447 U.S. at 444.

211 Id. (footnote omitted).

222 In dissent, Justice Powell rejected the distinction between natural resources and secondary products. Id. at 448 n.2. For one thing, he thought the "Court's definition of cement production describes all sophisticated economic activity, including the exploitation of natural resources." Id. Perhaps Justice Blackmun's definition was not artfully phrased, but the distinction certainly is intelligible if he was attempting to distinguish between different degrees of monopoly power. Justice Powell also suggested, however, that he would have imposed an obligation of equality when the state possesses either type of monopoly power. He emphasized that "in its regional market, South Dakota has unique access to cement." Id. (emphasis omitted). For him, it was enough that a "cutoff in cement sales has the same economic impact as a refusal to sell resources like natural gas." Id. 
nopoly. It remains to be seen whether the balance will tip in favor of nonresident need when state monopoly power is greater. ${ }^{223}$

Quite independently of the proprietary notion, then, the authority of South Dakota to sell its cement only to resident businesses could have been upheld on the principle of resident entitlement to nonmonopolized state-created resources. ${ }^{224}$ The only unfortunate thing about Reeves is that, although the elements of the principle were adverted to in the Court's opinion, they were displaced from their rightful place of honor by the ill-conceived proprietary exception doctrine.

2. State Educational Institutions. The same general analysis is equally applicable to state educational offerings. The state establishes public schools primarily for the purpose of serving residents. At the same time, it cannot constitutionally forbid the operation of private educational institutions within the state, and so it cannot monopolize education. ${ }^{225}$ The state also may not require its private institutions to prefer residents, ${ }^{228}$ but the Constitution should not disable the state from restricting attendance at public institutions to bona fide residents. ${ }^{227}$ Whether or not such a re-

${ }^{223}$ It should also be noted that Reeves was a case where the state's resource was not adequate to satisfy demand; thus sales to nonresidents precluded sales to residents. In short, it was not an "abundant" resource. See text at notes 177-180 supra. Whether the Court would reach the same conclusion with respect to an abundant resource is also an open question.

${ }^{224}$ For the same reasons, a state should be able to lease state-owned commercial property to residents first. When state revenues are responsible for the existence of state buildings, and nonresidents are not blocked from operating in alternative locations available in the private sector, a state is justified in allocating ordinary state property for the preferred use of residents.

The Fifth Circuit recently held to the contrary in the context of leases of state-owned sales space to resident farmers selling in competition with out-of-state farmers. Smith v. Department of Agriculture, 630 F.2d 1081 (5th Cir. 1980). The court applied the virtually per se rule of invalidity applicable to state regulations of private market activity designed to favor local businesses. Id. at 1084-85. But see note 84 supra.

A more sensitive approach to the case would have focused on the similarity between state financial subsidies provided only to resident businesses and this nonmonopolistic form of state in-kind subsidy provided only to resident businesses. The discussion in text at notes 194-206 supra, as well as the discussion here, support a result contrary to that reached in Smith.

225 Pierce v. Society of Sisters, 268 U.S. 510 (1925).

${ }^{238}$ There seems no reason to treat an embargo of private educational offerings differently than embargoes of private goods. See text and note at note 14 supra.

${ }_{227}$ This does not mean that a state is free to impose unduly strict requirements as to who shall be considered a bona fide resident. A state may not, for example, deny a fair opportunity to a former nonresident to demonstrate that he has become a bona fide resident eligible for reduced tuition at the state university. Vlandis v. Kline, 412 U.S. 441 (1973). Although the Court has upheld a one-year durational residency requirement as a means of 
striction is desirable as a matter of policy, Justice Blackmun's implicit approval in Reeves of resident preference policies in state schools seems correct.228

Little question has been raised about state power to reserve elementary and secondary public schools for resident use. Professor Simson, however, argues that state power to discriminate against nonresidents in state-provided higher education extends only as far as charging nonresidents more than residents, up to the full cost of the education provided, and does not include the power to set quotas on nonresident admission. ${ }^{228}$ Because the full cost can be recaptured, he argues that abandonment of nonresident quotas does not jeopardize the operation of the schools.230 Secondly, granting the substantiality of a state interest in providing residents with the educational benefits of small, high quality institutions, he claims that the power to charge nonresidents more enables the state to provide more of these types of schools if nonresident demand is great. He finds that "the state has no material interest in educating its residents in a specific school."231

There are several problems with this analysis. First, and least important, recapturing the full cost of educating nonresidents, but no more, would be an administratively difficult task. Even assuming that the state is given the benefit of the doubt in calculating the costs, the problems run much deeper. Expanded facilities to accommodate paying nonresidents may incur noneconomic costs, and these cannot easily be recouped. Size, location, and accessibility are only a few of the considerations that enter into the planning of educational institutions. If a state must choose between no public schools or serving all nonresidents who demand admission, are able to pay, and are otherwise equal to the residents the state

ensuring that only bona fide residents receive the benefit of reduced tuition, Starns $v$. Malkerson, 401 U.S. 985 (1971) (mem.), aff'g 326 F. Supp. 234 (D. Minn. 1970), it does not necessarily follow that the Court would uphold such a lengthy period if bona fide residence were a qualification to attend the state university at all. The greater interest in receiving an education than in paying reduced tuition might well tip the balance the other way. Moreover, though a state may be entitled to insist that one claiming residency has given up residence elsewhere, one can reasonably question whether the result in Starns is consistent with the individual right to choose to relocate from one state to another. In any event, it seems doubtful that the Court would allow any greater obstacle to becoming a resident.

228 See the language quoted in text at note 218 supra. On this issue, Justice Powell may agree. See Reeves, Inc. v. Stake, 447 U.S. 429, 447 n.1 (1980) (Powell, J., dissenting).

22: Simson, supra note 126 , at $395-97$.

230 Id. at 397.

231 Id. 
wishes to educate, it may hesitate before choosing the second option. A state might not wish to create a vast public educational establishment despite the ability to charge nonresidents more. This is especially true when the state must consider the possibility of future declines in nonresident enrollment. The state could not force nonresidents to enroll, and if the cost of maintaining a system large enough to meet current demand must be shared among a significantly smaller number of nonresidents in the future, nonresident tuition might increase to the point where most nonresidents lose interest, leaving the state with a white elephant. Moreover, it is difficult to understand why the states have no material interest in educating residents in particular schools that they create. The ability to provide particular kinds of educational experiences would seem to be at the heart of state power to serve state inhabitants. In sum, there is no strong reason to except state colleges and universities from the general state power to reserve state-created resources for the preferred, or exclusive, use of residents.

\section{State-Owned Natural Resources}

In an era increasingly conscious of the scarcity of depletable natural resources and the fragility of unique scenic resources, it should be unnecessary to emphasize the importance of the rules of access that will determine the distribution of such resources. In a federal system of government, recognition of the power of constituent political units to reserve the natural resources found within their jurisdiction for the use of their own inhabitants carries a serious potential for division of the nation along provincial lines, as Canada's recent experience well illustrates. ${ }^{232}$ Although constitutional barriers to state discrimination against out-of-staters are now well established with respect to natural resources that are either privately owned ${ }^{233}$ or possessed by no one, ${ }^{234}$ the power of states that own natural resources to favor their residents when those public resources are made available for use remains unsettled.

${ }^{232}$ See Balkanizing Canada: The Cost of Provincial Barriers, Bus. WeEk, Sept. 15, 1980 , at 52 .

2ss See, e.g., Pennsylvania v. West Virginia, 262 U.S. 553 (1923); West v. Kansas Natural Gas Co., 221 U.S. 229 (1911).

2s4 See Hughes v. Oklahoma, 441 U.S. 322 (1979); Foster-Fountain Packing Co. v. Haydel, 278 U.S. 1 (1928). 
The fortuitous geographical distribution of natural resources has a number of consequences related to state power. On the positive side, the presence of valuable natural resources within a state, regardless of who owns them, provides a basis for local economic prosperity, and, in the case of scenic resources, for aesthetic satisfaction and recreation. On the negative side, exploitation of natural resources seems inevitably to cause adverse effects on local residents, whether from pollution, overcrowding, or some other undesirable byproduct. The states must have power to control these adverse effects, of course, if they are to care for their residents. It does not necessarily follow, however, that the states must have the power to grant their residents a favored right to exploit state-owned natural resources, any more than the power to regulate the exploitation of privately owned natural resources implies state power to compel private sector favoritism towards residents. ${ }^{235}$ If state authority to prefer residents is to be upheld in this context, therefore, some other justification will be required.

The principles developed in this article can best be applied if the inquiry is divided according to the different kinds of natural resources a state might own. Although the common characteristic of natural resources is that they are not the products of human creation, some are living and reproducible and some are not, and some, though not reproducible, can be used repeatedly without being depleted. These distinctive attributes of different sorts of natural resources have an important bearing on the validity of resident preference schemes, and each type of natural resource will therefore be treated separately.

1. Natural Resources That Cannot Be Reproduced. A distinctive feature of some randomly distributed natural resources, such as mineral deposits, is that they are inanimate and exist without (and indeed cannot be created by) human action, whether by state political units or any other human agency. Thus the justification for state resident preference when a state creates and provides collective goods and services is not necessarily available when a state wishes to distribute nonreproducible natural resources that it owns. These resources exist without the need for communal cooperation.

2ss Nor does it follow from the right of a state to regulate natural resources located within its borders for the purpose of conservation that the state may favor residents when the resource is allowed to be exploited. See Cities Serv. Gas Co. v. Peerless Oil \& Gas Co., .340 U.S 179, 188 (1950). 
For this reason, I cannot agree with Professor Hellerstein's view that a rule preventing a state "from distributing or selling state-owned natural resources to in-state residents or businesses on a preferential basis" would be "disturbing."238 His argument is worth quoting in full:

To preclude the States from preferring in-state interests in the distribution of state natural resources would deprive the States of an important attribute of their separate existence as independent political units in the federal system. The denial to the States of the power to provide for their residents as such would undermine the relationship between the States and their residents. Moreover, forbidding the States from preferring their own in the distribution of their resources would introduce into the federal system an unsettling asymmetry between the respective obligations the resident and nonresident owe to the State and the benefits they enjoy there. ${ }^{237}$

Professor Hellerstein does focus on factors generally germane to state authority to prefer residents. But the untoward consequences of a rigid rule of nondiscriminatory access that are a justifiable concern when the resources are state-created seem to me not implicated when inanimate natural resources are in question. Neither the relationship between the states and their residents, nor the purposes of state political organization, require the ability to reserve state-owned natural resources for the use of residents. State experimentation and innovation are not curtailed, because the resources exist without state action. Nor does anything about the difference in the respective relationships between residents and their state, and nonresidents and the state, have any bearing on the location or allocation of those resources. Indeed, to the extent that these natural blessings provide the states in which they are found with a sounder tax base and greater economic potential, residents already enjoy a relative advantage over nonresidents. A further advantage is not deserved, nor is one necessary to fulfill state responsibilities, just because the resources happen to be located within the state.

One might refine the argument somewhat and contend that the state's power to prefer residents in the distribution of natural resources it owns should depend on the source of the state's owner-

${ }^{236}$ Hellerstein, supra note 44, at 77.

237 Id. 
ship. Although resource ownership stemming from original dominion should provide no justification for such a power, ${ }^{2 s 8}$ arguably the power should be recognized where the state uses state funds to purchase natural resources. But a second reason for withholding the power to discriminate on the basis of residence-the equality obligations of monopoly power-is still significant in this context. For another distinctive feature of nonreproducible state-owned natural resources is, by definition, that they cannot be reproduced by the private sector. As a general matter, then, so long as the state holds natural resources that cannot be replenished, it must provide equal access to nonresidents. The state's strongest case for resident preference would be presented when it purchased the resources in the open market and significant private supplies of the resource also existed within the state. Perhaps here, as long as the state did not control an important share of the resource deposits, authority to favor residents might be justified. Otherwise, a rule of nondiscriminatory access should be followed.

This analysis should govern the disposition of all nonreproducible resources owned by the states. It may be most important in the case of state ownership of mineral and energy deposits. These resources are depleted by consumption and the local claim to preferred distribution is weak and overshadowed by the importance of nationwide availability of the resource. But the same basic problem is presented where nonreproducible natural resources are capable of repeated use, whether for commercial or recreational purposes. Recall the problem presented in McCready $v$. Virginia, ${ }^{239}$ where the Supreme Court upheld Virginia's exclusion of nonresidents from the planting of oysters in the state's tidelands. The state's ownership of the tidelands should not have justified discrimination, because the tidelands are a unique natural resource, not reproducible by the private sector and not established by a state program. The absence of state creation and the equality obligations of monopoly power should have compelled nonresident access. If the state needed to limit oyster planting to preserve the

2ss Alaska, for example, received title to millions of acres of land, with full mineral rights, by conveyance from the federal government. See Hicklin v. Orbeck, 437 U.S. 518, 528 n.11 (1978). In any case where the state's wealth does not derive from the contributions of residents acting through the state, there is good reason to adhere strictly to obligations of interstate equality. That is especially true when the national government conveys property to a state without compensation.

230 94 U.S. 391 (1877), discussed in text at notes 26-31 supra. 
tidelands it could have done so in a nondiscriminatory manner. ${ }^{240}$ If it spent money to preserve them, it could have charged nonresidents for the costs created by their use. But exclusion was not justified. Because of the state's monopoly power, the Court's analogies-equating nonresident exclusion from the tidelands with nonresident exclusion from a share of the proceeds of the sale of public property and with nonresident exclusion from planting corn on state-owned land ${ }^{241}$-are inapposite. Once the state sells property, the resource it then distributes is money. Arable land is rarely unique; the private sector generally will control other land suitable for planting. Recognition of state power to distribute these public resources to residents does not require the same result when the issue is distribution of unique natural resources not available in the private sector.

A similar approach supports the conclusion that nonresidents and residents must have equal access to state beaches and parks. ${ }^{\mathbf{2 4 2}}$ Most state beach and park property is unique and not reproducible. It should therefore be subject to the rule of nondiscriminatory access regardless of the fact that its intended use is recreational..$^{243}$

2. Reproducible Natural Resources. The case for equality of nonresident access to state-owned natural resources is much more difficult to make when the resources are living and reproducible, because the state may well have invested public funds in increasing the originally available resource. Thus the produce of state farms and ranches is as much a creation of state programs as the cement produced from raw materials by South Dakota's cement plant, and the governing principles ought to be the same. As long as the state does not have monopoly power over the raw materials or plant or animal life necessary to produce or reproduce the commodities to be distributed, and as long as it does not forbid competition with itself within the state, the state ought to be free to parcel out state fruits, vegetables, timber, chickens, cattle, and the like to residents

210 See Hughes v. Oklahoma, 441 U.S. 322, 337-38 (1979).

241 See 94 U.S. at 395-96.

242 The case for equality may be even stronger here, because these resources are usually not used to capacity. The state interest in minimizing crowds and other noneconomic costs, although it exists, is not strong.

24s State-financed golf courses, tennis courts, and so on have to stand on a different footing. At least where the state can make a case for scarcity, and where no first amendment rights to a "public forum" are implicated, see generally Kalven, The Concept of the Public Forum: Cox v. Louisiana, 1965 Sur. Cr. Rev. 1, resident preference, if not hospitable, is at least justifiable because of the state creation of the resource. 
alone.

If a state were to own an entire species of plant or animal life, or enough of the species that private development was infeasible, one might expect that nonresidents could not be denied equal access to any distribution. One would certainly expect that result if the wildlife, peculiarly native to the state, was in neither state nor private possession. If the state does not "own" the wildlife in this sense, it can hardly claim to have created the resource. ${ }^{244}$ It will be recalled, however, that in Baldwin v. Fish \& Game Commission, ${ }^{246}$ Justice Blackmun (who later intimated in Reeves that state monopoly power over natural resources might restrict state power to favor residents when the nonresident seeks the commodity to earn a living ${ }^{246}$ ) upheld a state discrimination against nonresidents wishing to hunt elk that the state did not own. Because the reason given was that the privileges and immunities clause does not apply to claims of nonresident access for "nonfundamental" recreational purposes, ${ }^{247}$ we should not conclude that the Court would treat the commercial distribution of state-monopolized wildlife the same way. We know from Hughes $v$. Oklahoma ${ }^{248}$ that if the state does not own wildlife and the nonresident's purpose is commercial, then discrimination against interstate commerce is impermissible. What we do not know is whether, if elk were sought as a means of livelihood and Montana monopolized ownership of the elk supply, the Court would be inclined to follow the intimations of Reeves or would distinguish unique access to inanimate, depletable resources from unique control of reproducible resources.

In a valiant effort to explain the result reached in Baldwin without resting on what he also believes is the empty distinction between fundamental and nonfundamental activities, Professor Tribe suggests that perhaps the Court thought the "elk should be treated constitutionally as if they were the property of the state," because the state's effort to preserve them was equivalent to resource creation." ${ }^{249}$ Moreover, he thinks it "must be clear . . . that

246 This question may at first glance, however, appear to be complicated by conservation programs, habitat creation, the stocking of rivers and lakes, and the like. See text at notes 249-250 infra.

365 436 U.S. 371 (1978), discussed in text and notes at notes 88-118 supra.

246 See text and notes at notes 220-231 supra.

267 436 U.S. at 388. See the criticism of this analysis in text and notes at notes 97-118 supra.

248441 U.S. 322 (1979), discussed in text at notes 53-55, 63 supra.

${ }^{240}$ L. TriBe, supra note 46, at 38 (Supp. 1979). 
the Court is willing to tolerate significant discrimination against nonresidents because it cannot be sure, if a state like Montana is forced to act evenhandedly, that its citizens will not simply give up entirely the effort to conserve their wildlife."250 To take the latter point first, it is none too clear why the Court would not fashion a rule at least forbidding discrimination that cannot be cost justified. So long as the state can recoup the cost of conservation, the incentives to conserve would have the same weight as if nonresidents could be denied access. Besides, if this were the Court's conception, it would be equally applicable to commercial distribution. True, it is arguable that state incentives to conserve, despite requirements of nonresident equality, would be greater where residents stand to gain commercially from continued supply than where residents stand to gain only recreational opportunities. But the notion that expenditures to preserve wildlife are the equivalent of state creation is equally applicable to wildlife used for commercial and recreational purposes. To uphold state power to prefer residents because of the "creative" aspects of such expenditures would therefore suggest a similar rule when state-monopolized reproducible resources are commercially distributed. It would be better to assume that the Court really intended to rest the case on the fundamental/nonfundamental distinction than to supply a more substantive explanation of the case that risks undesirable results in other contexts. It would be better still, of course, if the emptiness of the articulated distinction in Baldwin were recognized. Perhaps, if left unsupported, it will in time fall of its own weight. At that point, discrimination on the basis of residence should be forbidden with respect to commercial, or recreational access. to state-monopolized wildlife. In the meantime, interstate equality should be required at least with respect to commercial access, and state expenditures for conservation should not be viewed as a justification for resident preference when the species conserved are available only from the state.

\section{Conditional Distribution of State Resources}

State subsidy of resident interests through direct distribution of public resources obviously can take many forms and raise a variety of issues. Still another set of questions arises, however, if a state limits eligibility to receive public resources to those (res- 
idents or nonresidents) who will themselves prefer residents in separate private dealings. The additional difficulty is because the state is constitutionally powerless to compel private parties to deal with residents. ${ }^{251}$ Using the lure of state resource availability to affect private relationships falls somewhere between forbidden compulsion and the permissible state power to allocate state resources directly to residents. Just as congressional exercises of the spending power that condition eligibility for grants on agreement to do what Congress lacks the power to command directly give rise to constitutional qualms, ${ }^{252}$ so, too, one should be suspicious of state inducement of private conduct that the state is forbidden to require through conditional entitlement to partake of state resources.

Again, there is a need to distinguish among the kinds of public resources that a state proposes to use as an inducement. Whenever the resource is such that the state cannot constitutionally prefer residents even in direct unconditional distribution, a fortiori it should not have the power to influence private parties to favor residents through conditional distribution. For example, if the Court were to agree with the conclusion that Alaska is not free to favor its residents in the allocation of state-owned oil and gas reserves, it would surely follow that Alaska could not condition the grant of rights to exploit the oil and gas on the licensee's willingness to hire residents first, or to favor residents as suppliers or customers.

Even if the Court allows state allocation of a public resource to residents first, it still might be concerned about the leverage a state can exert on private relationships through conditional distribution. There is some evidence that the Court does react this way, although the Justices have not expressly spoken in this vein, and the Court's experience with the problem is too limited to give rise to a comprehensive theory. In Hicklin $v$. Orbeck, ${ }^{253}$ it will be recal-

${ }^{2 s 1}$ See, e.g., Hicklin v. Orbeck, 437 U.S. 518 (1978); Pennsylvania v. West Virginia, 262 U.S. 553 (1923).

${ }^{232}$ Compare United States v. Butler, 297 U.S. 1 (1936) (invalidating the Agricultural Adjustment Act of 1933, which authorized a tax on agricultural processors and use of the monies collected to pay farmers to reduce crop production, as a coercive purchase of compliance with regulations Congress could not impose) with Steward Mach. Co. v. Davis, 301 U.S. 548,585 (1937) (upholding the unemployment compensation provisions of the Social Security Act, which gave a federal tax credit to employers required to contribute to Social Security for contributions made to a state unemployment fund meeting federal standards, finding no "coercion of the states in contravention of the Tenth Amendment or of restrictions implicit in our federal form of government"). See also Linde, Justice Douglas on Freedom in the Welfare State, 39 WAsH. L. REv. 4, 28-31 (1964).

sss 437 U.S. 518 (1978), discussed in text at notes 39-45 supra. 
led, a unanimous Court disapproved Alaska's attempt to use its ownership of oil and gas to require all who contracted with the state, and all who contracted with the state's contractors, to give employment preferences to Alaska residents. The Court found the breadth of the attempted control too great to be justified by the state's "proprietary interest."254 The apparent concern was that Alaska had attempted to pyramid its ownership of oil and gas into control of the private sector on such a wide basis that the program of conditional distribution was barely distinguishable from regulation. But the resemblance to regulation would be equally apparent if Alaska had only required direct contractors to favor resident interests, for the virtually coercive power that accompanies control of such scarce and valuable resources would be fully as effective as regulation in causing immediate contractors to bias their business decisions. It was really the conditions placed on eligibility to exploit the state resources, together with the state's bargaining power, that raised the problem-not the breadth of the program.

At the other end of the spectrum, where conditional distribution might be thought to resemble impermissible regulation least, is the conditional distribution of state funds. This was involved in Hughes v. Alexandria Scrap Corp., ${ }^{255}$ although the Court did not analyze the case this way. The offer of a bonus to those who deal with residents is obviously a conditional distribution. In dissent, Justice Brennan distinguished state purchases for state consumption from purchases in the midst of the stream of commerce. ${ }^{258} \mathrm{An}$ other way of thinking about the same problem is to distinguish between state expenditures for supply to the state and state expenditures to cause one private party to deal with another who is a resident; that is, the difference between conditional and unconditional dispositions of state funds.

If the use of state monies to influence private contracting choices is permissible where direct regulation would not be, perhaps it is because in cases like Alexandria Scrap the bonus payment for deliveries to in-state processors seems so much like an unconditional financial subsidy to the processors. Presumably they

254 Id. at 529.

2ss 426 U.S. 794 (1976), discussed in text at notes 68-70 supra.

${ }^{258} I d$. at 824 . He did so, however, only to suggest that the issue in Alexandria Scrap was even more difficult than the issue of the validity of state purchases for end use. Apparently, Justice Brennan (along with Justices White and Marshall, who joined his opinion) would not allow resident preference in either type of purchase where "economic protectionism" motivated the preference policy. Id. at 823 . 
would use such a subsidy to enhance the price they offered for abandoned cars and thereby attract business that might otherwise go to out-of-state processors. The validity of the analogy depends on the belief that a direct subsidy would be used to further the activity to which the conditional subsidy is tied. If a perception of this kind swayed the Court in Alexandria Scrap, the case would be narrow and would not even control all cases of conditional financial subsidies. For example, if a state sought to alleviate resident unemployment by paying a bonus to private employers to hire residents over nonresidents, one could not say that an unconditional subsidy to the private employers probably would achieve the same result; the employers might lower prices instead. Hence, the resemblance of this subsidy program to a regulatory program would be more apparent.

It is entirely possible-and perhaps more consistent with the language of the opinion- ${ }^{257}$ that the Court's view was broader, and that the majority was moved by the perception that a state ought to be able to buy a service from the private sector that it is free to provide itself. From this perspective, assuming that a state can subsidize resident business directly or provide state jobs for residents, it should also have the choice to accomplish its goals by purchasing private sector services. If this is the Court's view, however, it should be recognized how close to the pattern of control by regulation the conditional subsidy is.

Justice Powell's opinion in Alexandria Scrap does emphasize that the state merely intervened in the market by financial competition, ${ }^{268}$ thereby supporting this broader interpretation. Still unresolved is the question of state power to condition entitlement to public goods and services on the recipient's preference of residents. Justice Powell dissented in Reeves, where only the unconditional distribution of state goods in short supply was at issue. Ironically, though two members of the majority in Alexandria Scrap voted against the resident preference policy in Reeves, Justice Marshall, one of the dissenters in the former, supplied the fifth vote to up-

257 See text at notes 69-70 supra.

288 Thus he wrote that "Maryland has not sought to prohibit the flow of hulks, or to regulate the conditions under which it may occur. Instead, it has entered into the market itself to bid up their price." 426 U.S. at 806 . He went on to say that the state "elected the payment of state funds-in the form of bounties-to encourage the removal of automobile hulks from Maryland streets and junkyards." Id. at 809. Finally, he emphasized that the hulks "remain within Maryland in response to market forces, including that exerted by money from the State." Id. at 810 . 
hold state power to prefer residents in the latter. Unfortunately, as the only Justice to vote against state power in Alexandria Scrap and for it in Reeves, Justice Marshall did not write an opinion in either case. But his position in both cases is consistent-and, I think, correct-insofar as it represents a view that a state may distribute nonmonopolized, state-provided resources to residents first, but may not use the leverage of access to those resources in order to bias private relationships toward parochial interests. If South Dakota had declared that it would only sell cement to customers who would favor residents when they bought, sold, or hired, I suspect Justice Marshall would have made a majority to strike down the state policy.

In sum, when a state attempts to use public resource distribution to control relationships within the private sector, its power should be more limited than when it uses unconditional public resource distribution to aid residents. The Court's decisions are not necessarily to the contrary. Furthermore, the more leverage is provided by the particular resource the state plans to use as a carrot, the more the carrot resembles a stick. The leverage obtained by attaching strings to financial subsidies, if itself justified, should be the outer limit of state power to exert influence over private relationships. When the state gets its leverage from having the only available cement or other lures of state business, it should be precluded from using its greater bargaining power to accomplish indirectly-and too effectively-what it is forbidden to compel directly.

\section{The Power of Congress to Affect State Resident Preference Programs}

The Supreme Court always has taken, and undoubtedly will continue to take, a leading role in accommodating state and interstate interests when issues of discrimination against nonresidents or nonresident business are raised. ${ }^{258}$ But Congress, too, may choose to play a part, and if it does, the focus shifts from the constitutionality of state power to the constitutionality of federal power. Two polar types of congressional action are likely to be questioned: prohibiting states from favoring residents in circum-

268 The foundations of judicial enforcement of the commerce clause are explained in note 4 supra. The Court's enforcement of the privileges and immunities clause flows even more directly from the constitutional text than does its enforcement of the negative implications of the commerce clause. 
stances where the Court would otherwise find the state authority constitutional, and consenting to state resident preference where the Court would find state authority lacking had Congress not spoken.

\section{A. Congressional Prohibition of State Resident Preference}

Whenever state power to favor resident interests is constitutionally justified because the state is fulfilling the special obligations it owes its own citizens, congressional attempts to limit the favoritism will run into the claim of unconstitutional interference with state autonomy. ${ }^{260}$ For those who believe that state autonomy interests are sufficiently protected by the national political process, ${ }^{281}$ no judicial determination of congressional power would be necessary, although the constitutional question might be important in the congressional debate itself. ${ }^{262}$ But in any event, a majority of the present Court is prepared to extend judicial protection to perceived constitutional state autonomy interests.

National League of Cities $v$. Usery ${ }^{263}$ is the necessary starting point. It is the only decision in over forty years to strike down an act of Congress for violating state autonomy. In that case, the Court held Congress powerless to mandate state wage and hour policy with respect to state employees engaged in the performance of "integral operations in areas of traditional governmental functions."264 The Court did not question federal power to set wage and hour requirements to be followed by either private employ$\mathrm{ers}^{265}$ or state employers with respect to employees engaged in

${ }^{200}$ For a good discussion of state autonomy interests in the face of congressional regulation, see Stewart, Pyramids of Sacrifice? Problems of Federalism in Mandating State Implementation of National Environmental Policy, 86 YALE L.J. 1196, 1210-11, 1231-68 (1977).

${ }^{281}$ See generally National League of Cities v. Usery, 426 U.S. 833, 876-78 (1976) (Brennan, J., joined by White \& Marshall, JJ., dissenting); J. ChOPER, Judrcial REviEw AND THE National Polimical Process 171-259 (1980); Wechsler, The Political Safeguards of Federalism: The Role of the States in the Composition and Selection of the National Government, 54 CoLum. L. Rev. 543 (1954).

${ }^{262}$ See generally Brest, The Conscientious Legislator's Guide to Constitutional Interpretation, 27 Stan. L. REv. 585 (1975).

2es 426 U.S. 833 (1976).

284 Id. at 852.

${ }^{285}$ That power was upheld in United States v. Darby, 312 U.S. 100 (1941), the continuing vitality of which the Court did not question. In National League of Cities itself the Court rejected the argument that federal preemption of state regulation of the private sector was as much an impairment of state sovereignty as federal regulation of the state as employer. Justice Rehnquist wrote: 
state commercial activity. ${ }^{266}$

Applying National League of Cities' dichotomy of state functions to issues of resident preference, there should be little doubt about congressional power to ban state discrimination in the context of state business or state aid to private business. If Congress can mandate state compliance with federal safety regulations on state-owned railroads ${ }^{267}$ and with federal wage and hour requirements for employees engaged in state business, it should also have the power to forbid discrimination against nonresidents who want to buy from, sell to, or work for state businesses, and to forbid state subsidies limited to resident businesses. Surely if Congress concludes that these discriminations adversely affect national productivity, the commerce power supplies ample authority to deal with the problem.

But suppose Congress outlaws exclusion of nonresidents from state welfare programs, public schools, public housing, or state jobs in "areas of traditional governmental functions"? Here the state autonomy concerns underlying National League of Cities are more troublesome. Inclusion of nonresidents in each of these programs would require a state to spend much more in order to serve its residents fully. In the case of welfare and perhaps public housing, the state might well choose to reduce or eliminate its programs rather than extend eligibility to nonresidents. Requiring equal consideration for "integral" state jobs might present less of a problem, at least where the state is not acting as employer of last resort, because such jobs presumably will be provided in any case. But here, the argument of freedom to "structure" relationships with

It is one thing to recognize the authority of Congress to enact laws regulating individual businesses necessarily subject to the dual sovereignty of the government of the Nation and of the State in which they reside. It is quite another to uphold a similar exercise of congressional authority directed, not to private citizens, but to the States as States.

426 U.S. at 845. Later in his opinion, Justice Rehnquist emphasized that "we have reaffirmed today that the States as States stand on a quite different footing from an individual or corporation when challenging the exercise of Congress' power to regulate commerce." Id. at 854 .

286 In addition to restricting its holding to "integral operations in areas of traditional governmental functions," $i d$. at 852, the Court expressly disclaimed any intention to overturn the holdings of United States v. California, 297 U.S. 175 (1936), which sustained congressional authority to require a state-owned, nonprofit railroad available for public hire to comply with federal safety requirements, or California v. Taylor, 353 U.S. 553 (1957), which upheld application of the federal Railway Labor Act to employment relationships between a state-owned railroad and its employees. 426 U.S. at 854 n.18.

${ }^{267}$ United States v. California, 297 U.S. 175 (1936). 
residents in the provision of traditional state services can be made. ${ }^{268}$

On the other hand, congressional power to regulate commerce is supplemented by congressional power to enforce the equal protection clause of the fourteenth amendment, ${ }^{269}$ which extends its protective mantle to classifications based on state of residence. ${ }^{270}$ Under the rationale of Katzenbach $v$. Morgan, ${ }^{271}$ which recognizes congressional power to prohibit state discrimination permitted by judicial interpretations of the Constitution, Congress should have powers beyond those granted by the commerce clause to prohibit state resident preferences. Moreover, a few older Supreme Court cases arguably imply, albeit weakly, direct congressional power to enforce the interstate privileges and immunities clause. ${ }^{272}$ These precedents fall far short of asserting an article IV, section 2 enforcement power comparable to that recognized in Morgan under section 5 of the fourteenth amendment, but it is hardly a radical proposition to assume that Congress should have the power to act in the interest of interstate unification.

These combined congressional powers may well be adequate to uphold virtually any ban on state resident preferences despite the implications of National League of Cities. I do not undertake a more comprehensive examination of this problem here, because this type of congressional action is not likely to be common given

28s In Reeves, Inc. v. Stake, 447 U.S. 429, 441 (1980), part of Justice Blackmun's response to the claim that the state's preference for resident customers violated the commerce clause was the observation that "[s]uch a holding . . . would interfere significantly with a State's ability to structure relations exclusively with its own citizens."

${ }^{200}$ See generally L. TRIBE, supra note 46, § 5-14. In National League of Cities, the Court was careful to "express no view as to whether different results might obtain if Congress seeks to affect [even] integral operations of state governments by exercising authority granted it under other sections of the Constitution such as ... $\$ 5$ of the Fourteenth Amendment." 426 U.S. at 852 n.17.

270 See Baldwin v. Fish \& Game Comm'n, 436 U.S. 371, 388-91 (1978).

271384 U.S. 641 (1966).

${ }^{272}$ In United States v. Harris, 106 U.S. 629 (1882), the Court struck down a federal criminal statute prohibiting private conspiracies to deprive any person of "equal protection of the laws or equal privileges or immunities under the laws." The Court found no constitutional basis for Congress to outlaw individual, as opposed to state, interference with these rights. The Court considered article IV, section 2 as a possible basis of congressional authority, but determined that it, "like the Fourteenth Amendment, is directed against State action." Id. at 643 . The implication is that there would be congressional power to prevent state interference with rights protected by the privileges and immunities clause. The holding, as well as the implication, of Harris was reaffirmed in Baldwin v. Franks, 120 U.S. 678, 689-90 (1887), and United States v. Wheeler, 254 U.S. 281, 298 (1920). 
the operation of the "political safeguards of federalism."27s Also, the potential variations in the circumstances where Congress might so act would require such a lengthy analysis as to preclude a hypothetical approach. But it is important to be aware that the state autonomy interests that justify state power to discriminate in favor of residents may come into conflict with congressional interests in fostering interstate cohesion. Recognizing the superiority of federal power in some contexts would mean substantial, or even total, restriction of state ability to provide preferences to its residents as a class.

\section{B. Congressional Consent to State Resident Preference}

Equally difficult issues are raised by congressional authorization of otherwise unconstitutional state resident preferences. Prevailing commerce clause doctrine already recognizes congressional power to bless state discriminations against interstate commerce that the Supreme Court would find-or already has found- incompatible with the unexercised commerce clause. ${ }^{274}$ The Court has had some difficulty explaining the existence of this power, ${ }^{275}$

${ }^{273}$ See generally authorities cited note 261 supra.

274 The leading case is Prudential Ins. Co. v. Benjamin, 328 U.S. 408 (1946), which upheld a South Carolina tax on insurance premiums received from in-state business that was imposed only on out-of-state insurance companies. Although the tax clearly discriminated against interstate commerce, the Court construed the McCarran-Ferguson Act as authorizing it, id. at $427-33$, and upheld the power of Congress to authorize a state's discriminatory tax, id. at $418-27$.

${ }^{275}$ See id. at 425-26, where Justice Rutledge wrote that in cases where the Court had held state conduct violative of the commerce clause before Congress had acted on the subject and then upheld the same state conduct after Congress had acted affirmatively to approve it, the

sustaining of Congress' overriding action has involved something beyond correction of erroneous factual judgment in deference to Congress' presumably better-informed view of the facts, and also beyond giving due deference to its conception of the scope of its powers, when it repudiates, just as when its silence is thought to support, the inference that it has forbidden state action.

Professor Dowling said of this passage:

At this point it seemed almost as if Mr. Justice Rutledge were leading to a mountain top from which he would point out the 'something beyond' which really went to the root of the matter. But after looking at this point and that on the broad landscape of his opinion, I was still not sure that my vision had caught the something beyond. Dowling, Interstate Commerce and State Power-Revised Version, 47 Colum. L. Rev. 547, 557 (1947).

A century earlier, the Court had taken the apparently contrary position that insofar as the states "were divested of the power to legislate . . . by the grant of the commercial power to Congress," Congress could not "regrant, or in any manner reconvey to the States that power." Cooley v. Board of Wardens, 53 U.S. (12 How.) 299, 317 (1851). 
but no doubt that the constitutional limitation is itself implied from an affirmative grant to Congress, together with Chief Justice Marshall's still-accepted definition of the commerce power as the power "to prescribe the rule by which commerce is to be governed," sional determinations that some state discriminations be permitted.

Even granting the legitimacy of some congressional power to authorize state discrimination against interstate commerce, however, what if Congress were to authorize state discriminations that would otherwise violate article IV, section 2? Could Congress, after Hicklin v. Orbeck, ${ }^{277}$ empower Alaska to reinstitute a residentpreference-in-employment law? Or could it authorize state taxes on the in-state wages of nonresident commuters at the same time no tax is applied to the wages of residents? ${ }^{278}$

One of the difficulties in granting Congress such power is that the direct limitation on state power contained in article IV, section 2 , unlike that in the commerce clause, is not textually linked with any affirmative grant of power to Congress. Moreover, even if the Court were disposed to recognize implicit congressional power to enforce the interstate antidiscrimination principle of that section, ${ }^{279}$ and even if the Court would uphold congressional enforcement power when the Court would not independently find state discrimination unconstitutional, it does not follow that congressional power to dilute the antidiscrimination provision would also be implied. On the contrary, Katzenbach $v$. Morgan, ${ }^{280}$ although it held that the fourteenth amendment's express grant of congressional enforcement power allowed congressional imposition of greater restraints on state discrimination than would be imposed by judicial interpretations of the amendment, also expressly denied any congressional power "to restrict, abrogate, or dilute" the amendment's equality guarantees. ${ }^{281}$ Certainly one can mount a strong argument that the interstate equality guarantee of article IV, section 2 likewise is immune from congressional abrogation.

This is the assumption of Professor Tribe, who asserts that

278 Gibbons v. Ogden, 22 U.S. (9 Wheat.) 1, 196 (1824).

277437 U.S. 518 (1978), discussed in text at notes 39-43 supra.

278 The Court held such a tax scheme to be inconsistent with the privileges and immunities clause in Austin v. New Hampshire, 420 U.S. 656 (1975).

270 See note 272 supra.

${ }^{280} 384$ U.S. 641 (1966).

281 Id. at 651 n.10. 
recognition of congressional power to consent to discrimination against interstate commerce

cannot properly be extended to a conclusion that Congress has limitless power to authorize state discrimination against out-of-state citizens. The privileges and immunities clause of article IV, § 2, for example, confers a personal right against state action unjustifiably discriminating against out-of-state citizens whether or not such discrimination is congressionally authorized. ${ }^{282}$

May we assume, however, that article IV, section 2 confers a personal right? Its location in the states' relations article ${ }^{283}$ does not reinforce the comfortable, traditional assumption that guarantees of equality are protective of individual and group liberty. Furthermore, it is necessary to account for the common origin in the Articles of Confederation of the antidiscrimination principles of both the commerce clause and the privileges and immunities clause. $^{284}$ If the equality guarantee of article IV, section 2 confers a personal right, why is the equality guarantee of the commerce clause less effective? Conversely, if Congress has the power to authorize state discrimination against interstate commerce despite the resulting impairment of interstate unification, why should Congress lack the power to authorize state discrimination against nonresidents on the theory that this, too, better suits the needs of "Our Federalism"? ${ }^{285}$ Nothing in the history of the framing or adoption of the Constitution suggests that these two clauses were deliberately separated to allow Congress to authorize discrimination in one context but not in the other, ${ }^{286}$ and the possibility of viewing article IV, section 2 as a federalism provision subject to revision by Congress cannot be discounted.

My own view, given the constitutional goal of national cohesion and the difficulties of articulating the constitutional basis of

${ }^{282}$ L. TRIBE, supra note $46, \S 6-31$, at 403 n.18 (emphasis in original).

285 Article IV of the Constitution generally is addressed to problems of interstate relationships, such as the effect of one state's legal proceedings in another state, $\S 1$, return of fugitives, $\S 2$, cl. 2, and the admission of new states by Congress, $\S 3, \mathrm{cl}$. 1 .

284 See Baldwin v. Fish \& Game Comm'n, 436 U.S. 371, 379 (1978). See also text at notes 1-6 supra.

${ }^{285}$ See Younger v. Harris, 401 U.S. 37, 44 (1971).

${ }^{288}$ It is not clear why the separation was made, but in Baldwin v. Fish \& Game Comm'n, 436 U.S. 371, 379-80 (1978), Justice Blackmun wrote: 'Their separation may have been an assurance against an anticipated narrow reading of the Commerce Clause. See Ward v. Maryland, 12 Wall. 418, 430-32 (1871)." 
congressional power to sanction state discriminations against interstate commerce, is that the asymmetry should be eliminated by negating congressional power to authorize discrimination in either context. But if the Court decided to accept an asymmetrical view of congressional power, it should at least be aware of the importance of resting a given decision on the commerce clause rather than the privileges and immunities clause, or vice-versa, in the many cases where both are available grounds of decision. ${ }^{287}$ For in a case like Toomer $v$. Witsell, ${ }^{288}$ where the Court split on whether to hold a state law invalid under article IV, section 2 or under the commerce clause, the power of Congress to modify the results of the decision and authorize the state discrimination at issue would be determined by which constitutional basis the Court chooses. This effect of an asymmetrical congressional power is another argument for making congressional power in each context congruent. Again, it would be preferable to adopt a uniform rule that bars authorization of discrimination than a uniform rule that approves the power to sanction discrimination.

\section{ConCLUSION}

Issues of discrimination and issues of federalism are frequently linked in constitutional discourse. Nowhere is this more true than when the constitutional legitimacy of state power to discriminate in favor of state residents is questioned. State freedom to satisfy the needs of state inhabitants often conflicts with nonresident claims to equal shares of the opportunities available throughout the union. I have argued that a focus on distinctions in the obligations respectively owed to state government by residents and nonresidents, and on distinctions based on the reciprocal obligations the state owes to these two classes-that is, a theory of state "citizenship" in the broadest sense-is the appropriate starting point for assessing the validity of any state discrimination on the basis of residence. Without necessarily. insisting that state residents possess constitutionally enforceable rights to state-provided benefits, ${ }^{289}$ a theory of state citizenship should recognize that if

287 In most cases where nonresidents seek to deal with residents within the state, or to export items out of state, it will be possible to invoke either clause. See generally text at notes 46-55 supra.

283334 U.S. 385 (1948), discussed in text and notes at notes 32-38, 51-52 supra.

280 But see Michelman, States' Rights and States' Roles: Permutations of 'Sovereignty' in National League of Cities v. Usery, 86 YALE L.J. 1165 (1977); Tribe, Unraveling National 
state representatives do choose to provide for the public welfare through affirmative government-created programs, the primary "public" for which they act is the state's citizenry. At the same time, the state political communities must function within the wider national political community and may not favor their own in ways that will shut out nonresidents from in-state benefits only the state can provide.

The legal and philosophical problems of communities within communities are varied and perplexing. Even in this discrete corner of that vast labyrinth, the challenge of letting the smaller community carry out its functions without becoming isolated from, or unduly excluding the members of, the broader community, appears in many forms. It is necessary to deal separately with the peculiarities of each form in order to negotiate the maze successfully. Perhaps the guideposts offered here hold some promise of assistance.

League of Cities: The New Federalism and Affrmative Rights to Essential Government Services, 90 HaRv. L. REv. 1065 (1977). 